\title{
Expanded Host Range Testing for Verticillium nonalfalfae: Potential Biocontrol Agent Against the Invasive Ailanthus altissima
}

M. T. Kasson, E. S. O’Neal, and D. D. Davis, Department of Plant Pathology and Environmental Microbiology, The Pennsylvania State University, University Park 16802

\begin{abstract}
Kasson, M. T., O’Neal, E. S., and Davis, D. D. 2015. Expanded host range testing for Verticillium nonalfalfae: potential biocontrol agent against the invasive Ailanthus altissima. Plant Dis. 99:823-835.

The naturally occurring Verticillium nonalfalfae has been proposed as a biocontrol agent against the highly invasive Ailanthus altissima in the eastern United States. We tested 71 nontarget woody species for susceptibility to the potential biocontrol agent. In the field, only devil's walkingstick ( $17 \%$ incidence) and striped maple (3\%) acquired infections through natural spread from infected A. altissima (100\%). Staghorn sumac (16\% incidence) also exhibited wilt in close proximity to diseased Ailanthus, although $V$. nonalfalfae was never recovered. Stem inoculations, which are highly artificial in that they bypass root defenses and flood the xylem with millions of conidia, induced varying levels of wilt and mortality in 10 nontarget species from which $V$. nonalfalfae was

reisolated, although recovery and crown rebuilding occurred following initial wilt in several species including sassafras and northern catalpa. Thirty-seven of the 71 inoculated species exhibited vascular discoloration, although 23 of these species exhibited no outward symptoms (wilt, dieback) for up to 6 years postinoculation. However, $V$. nonalfalfae was reisolated from three of the 23 species, indicating a tolerant host response. Our results suggest that $V$. nonalfalfae is generally hostadapted to A. altissima with 78 of 78 A. altissima seed sources from 26 states and Canada showing susceptibility, and offers support for adoption and dissemination of $V$. nonalfalfae to combat the highly invasive A. altissima.
\end{abstract}

Verticillium wilt caused by Verticillium nonalfalfae is a devastating vascular wilt disease of hops, kiwifruit, solanaceous plants, spinach, and other agricultural crops $(2,21,22,25)$. V. nonalfalfae is also a pathogen of forest trees and shrubs, including deerbrush (Ceanothus integerrimus Hook. and Arn.) $(15,25)$ and striped maple (Acer pensylvanicum L.) $(18,25,37)$. Most recently, V. nonalfalfae was recovered from symptomatic devil's walkingstick (Aralia spinosa L.) in Pennsylvania, although pathogenicity of recovered isolates were not evaluated (25). Over the past decade, $V$. nonalfalfae has been identified as the causal agent of wilt and mortality of tens of thousands of the highly invasive tree-ofheaven (Ailanthus altissima (Mill.) Swingle) in Pennsylvania $(25,36)$, Virginia (42,43), and Ohio (34), indicating that Ailanthus is not only very susceptible to $V$. nonalfalfae, but also is an important environmental reservoir for $V$. nonalfalfae in the eastern United States.

Given the pervasiveness of the naturally occurring, soilborne $V$. nonalfalfae throughout the introduced range of Ailanthus in the eastern United States, as well as its high level of virulence on this host, $V$. nonalfalfae is being considered as a biological control agent against Ailanthus within forests of Pennsylvania (25) and Ohio (20).

Previous host range studies of $V$. nonalfalfae $(=V$. albo-atrum $)$ on co-occurring tree species (37) revealed that only Ailanthus (100\% of inoculated individuals) and striped maple (100\%) developed wilt and mortality following inoculation, despite previous reports that seven of eight species tested were susceptible to V. albo-atrum (32,

Current address: West Virginia University, Division of Plant and Soil Sciences, Morgantown, WV 26506

Corresponding author: M. T. Kasson, Email: mtkasson@mail.wvu.edu

*The $\boldsymbol{e}$-Xtra logo stands for "electronic extra" and indicates that 2 supplementary figures and 3 supplementary tables are included in the online edition.

Accepted for publication 20 November 2014.

http://dx.doi.org/10.1094/PDIS-04-14-0391-RE

(C) 2015 The American Phytopathological Society
Table 1). More importantly, natural infections of co-occurring forest species by $V$. nonalfalfae were observed only in striped maple within stands where $V$. nonalfalfae was causing severe wilt and mortality of all $\mathrm{Ai}$ lanthus trees. Where natural infections of striped maple did occur, only approximately $1 \%$ of individuals were actually infected, suggesting a low risk for this species if such a stand is subjected to biocontrol efforts using $V$. nonalfalfae. These field results may indicate that $V$. nonalfalfae associated with lethal wilt of Ailanthus is hostadapted (37). Indeed, recent comparative pathogenicity testing supports host adaptation within $V$. nonalfalfae (25).

Despite promising short- and long-term efficacy studies regarding the virulence of $V$. nonalfalfae on Ailanthus in Pennsylvania $(25,36)$, intraspecific host range testing within Ailanthus populations has involved only a limited number of Ailanthus seed sources from a relatively restricted geographic area $(37,42)$. There is a need for additional susceptibility testing involving a more diverse panel of Ailanthus genotypes present within the United States $(1,39)$ to document possible intraspecific variation to $\mathrm{Ver}$ ticillium infections, as reported in other susceptible tree hosts $(26,45,46)$. Plant host range testing and risk analyses with $V$. nonalfalfae from Ailanthus has, thus far, been limited to inoculation experiments on several co-occurring native tree species (37). In total, $V$. nonalfalfae has been molecularly confirmed from 12 symptomatic plant hosts. Pathogenicity testing was performed on nine of these hosts and confirmed to various degrees $(21,22,25)$. More comprehensive long-term host range tests are needed to investigate whether other species that co-occur with Ailanthus are susceptible to $V$. nonalfalfae during and after severe Verticillium wilt outbreaks on Ailanthus.

Because so little is known about the biology of individual Verticillium species due to taxonomic confusion and cryptic speciation, determining accurate host ranges has been scientifically challenging. $V$. albo-atrum Reinke \& Berthold is a morphospecies, hereafter referred to as " $V$. albo-atrum" to denote the morphospecies in a wide or broad sense (i.e., 'sensu lato'), which now includes three formally recognized phylogenetic species: V. albo-atrum sensu stricto, $V$. alfalfae, and $V$. nonalfalfae (21). Preliminary host range testing of $V$. nonalfalfae isolate VnAa140 (formerly "V. albo-atrum" isolate PSU140), differed from previous reports of host species susceptibility to " $V$. albo-atrum" $(8,9,19,30,32)$. Many of the previously published host range lists for 
Table 1. Plant species artifically inoculated with Verticillium nonalfalfae isolate VnAa140

\begin{tabular}{|c|c|c|c|c|c|c|}
\hline Family, genus, species ${ }^{v}$ & Common name & Status $^{w}$ & Inoculation dates ${ }^{x}$ & No. reps ${ }^{y}$ & DBH $(\mathbf{c m})$ & Loc. $^{\mathrm{z}}$ \\
\hline \multicolumn{7}{|l|}{$\overline{\text { Angiosperms }}$} \\
\hline \multicolumn{7}{|l|}{ Aceraceae } \\
\hline Acer negundo L. ${ }^{1,3}$ & Boxelder & $\mathrm{N}$ & 2010 & 2 & 15.3 & 19 \\
\hline Acer palmatum Thunb. ${ }^{3}$ & Japanese maple & I & 2009,2010 & $1 / 2$ & $6.2 / 5.1$ & 16 \\
\hline Acer pensylvanicum L. ${ }^{1,2}$ & Striped maple & $\mathrm{N}$ & 2007,2010 & $3 / 1$ & $6.5 / 5.3$ & 15,4 \\
\hline Acer platanoides L. ${ }^{1,4}$ & Norway maple & INV & 2010 & 2 & 15.5 & 19 \\
\hline Acer rubrum L. ${ }^{1,3}$ & Red maple & $\mathrm{N}$ & 2007 & 3 & 24.7 & 15 \\
\hline Acer saccharum L. ${ }^{1,3}$ & Sugar maple & $\mathrm{N}$ & 2007 & 2 & 28.2 & 15 \\
\hline \multicolumn{7}{|l|}{ Anacardiaceae } \\
\hline Rhus typhina L. $^{1,3,6}$ & Staghorn sumac & $\mathrm{N}$ & 2009,2010 & $1 / 2$ & $9.2 / 4.8$ & 4 \\
\hline Toxicodendron radicans (L.) Kuntze ${ }^{5}$ & Poison-ivy & $\mathrm{N}$ & 2010 & 2 & 3.2 & 5 \\
\hline \multicolumn{7}{|l|}{ Annonaceae } \\
\hline Asimina triloba Dunal & Pawpaw & $\mathrm{N}$ & 2010 & 2 & 3.7 & 21 \\
\hline \multicolumn{7}{|l|}{ Araliaceae } \\
\hline Aralia elata (Miq.) Seem. & Angelica tree & INV & 2010 & 2 & 3.0 & 17 \\
\hline \multicolumn{7}{|l|}{ Betulaceae } \\
\hline Alnus glutinosa (L.) Gaertn. & European black alder & INV & 2010 & 2 & 17.1 & 19 \\
\hline Betula lenta L. $^{1}$ & Black birch & $\mathrm{N}$ & 2010 & 2 & 19.5 & 12,16 \\
\hline Carpinus caroliniana Walter ${ }^{1}$ & American hornbeam & $\mathrm{N}$ & 2010 & 1 & 5.0 & 2 \\
\hline Ostrya virginiana (Mill.) K.Koch ${ }^{1}$ & Hophornbeam & $\mathrm{N}$ & 2010 & 2 & 10.4 & 2,12 \\
\hline \multicolumn{7}{|l|}{ Berberidaceae } \\
\hline Berberis thunbergii DC. ${ }^{3}$ & Japanese barberry & INV & 2009 & 1 & $<1$ & 10 \\
\hline \multicolumn{7}{|l|}{ Bignoniaceae } \\
\hline Catalpa speciosa Warder ex Engelm..$^{1,3}$ & Northern catalpa & $\mathrm{N}$ & 2009,2010 & $1 / 2$ & $13.4 / 12.7$ & 5 \\
\hline Bignonia capreolata L. 5 & Crossvine & N-US & 2010 & 2 & $<1.0$ & $\mathrm{GH}$ \\
\hline \multicolumn{7}{|l|}{ Caprifoliaceae } \\
\hline Sambucus racemosa L. ${ }^{5}$ & Red elderberry & $\mathrm{N}$ & 2010 & 2 & 1.8 & 4 \\
\hline Viburnum plicatum Thunb. $^{3}$ & Doublefile viburnum & $\mathrm{I}-\mathrm{W}$ & 2010 & 2 & 3.3 & 19 \\
\hline Viburnum prunifolium L. 1,4 & Blackhaw & $\mathrm{N}$ & 2010 & 2 & 5.8 & 16 \\
\hline \multicolumn{7}{|l|}{ Celastraceae } \\
\hline Celastrus orbiculatus Thunb. & Oriental bittersweet & INV & 2010 & 1 & & 19 \\
\hline Euonymus alatus (Thunb.) Siebold & Burningbush & INV & 2010 & 2 & 3.6 & 19 \\
\hline Euonymus fortunei (Turcz.) Hand.-Maz. & Winter creeper & $\mathrm{I}-\mathrm{W}$ & 2010 & 2 & $<3$ & 19 \\
\hline \multicolumn{7}{|l|}{$\begin{array}{l}\text { Cornaceae } \\
\text { S }\end{array}$} \\
\hline Cornus florida L. 1,3 & Flowering dogwood & $\mathrm{N}$ & 2009,2010 & $1 / 2$ & 7.9/9.7 & 12 \\
\hline \multicolumn{7}{|l|}{ Elaeagnaceae } \\
\hline Elaeagnus umbellata Thunb. ${ }^{1,4}$ & Autumn olive & INV & 2010 & 2 & 2.7 & 9,12 \\
\hline \multicolumn{7}{|l|}{ Ericaceae } \\
\hline Kalmia latifolia $\mathrm{L}$. & Mountain laurel & $\mathrm{N}$ & 2010 & 2 & 3.1 & 20 \\
\hline Rhododendron maximum $\mathrm{L}^{4}{ }^{4}$ & Great rhododendron & $\mathrm{N}$ & 2010 & 2 & 5.3 & 21 \\
\hline Rhododendron periclymenoides Michx. ${ }^{4}$ & Pink azalea & $\mathrm{N}$ & 2010 & 2 & $<1$ & 3 \\
\hline Vaccinium angustifolium Aiton 5 & Lowbush blueberry & $\mathrm{N}$ & 2010 & 2 & $<1$ & 3 \\
\hline \multicolumn{7}{|l|}{ Fabaceae } \\
\hline Albizzia julibrissin Durazz. $^{5}$ & Persian silktree & I & 2010 & 2 & 6.3 & 24 \\
\hline Cercis canadensis L. ${ }^{1,3}$ & Eastern redbud & $\mathrm{N}$ & 2009,2010 & $1 / 2$ & $8.3 / 6.2$ & 11 \\
\hline Gleditsia triacanthos L. ${ }^{1,5}$ & Honey locust & $\mathrm{N}$ & 2010 & 1 & 14.2 & 11 \\
\hline Robinia pseudoacacia L. $^{1,3,6}$ & Black locust & $\mathrm{N}$ & 2009,2010 & $1 / 2$ & $13.1 / 12.6$ & 17,22 \\
\hline \multicolumn{7}{|l|}{ Fagaceae } \\
\hline Castanea dentata (Marsh.) Borkh. ${ }^{1,4}$ & American chestnut & $\mathrm{N}$ & 2010 & 2 & 3.8 & 3,18 \\
\hline Fagus grandifolia Ehrh. 1,5 & American beech & $\mathrm{N}$ & 2010 & 1 & 13.6 & 3 \\
\hline Quercus rubra L. ${ }^{1,3,6}$ & Northern red oak & $\mathrm{N}$ & 2007 & 2 & 47.0 & 15 \\
\hline Quercus prinus L. ${ }^{1,4}$ & Chestnut oak & $\mathrm{N}$ & 2007 & 2 & 35.5 & 15 \\
\hline Hamamelidaceae & & & & & & \\
\hline Hamamelis virginiana L. $^{1}$ & Witch-hazel & $\mathrm{N}$ & 2010 & 2 & 2.7 & 11 \\
\hline Hydrangeaceae & & & & & & \\
\hline Philadelphus sp. L. & Mock-orange & I & 2010 & 2 & $<1 \mathrm{~cm}$ & 19 \\
\hline Juglandaceae & & & & & & \\
\hline Carya sp. (Lam.) Nutt. ${ }^{1,5,6}$ & Hickory & $\mathrm{N}$ & 2010 & 2 & 11.3 & 11 \\
\hline Juglans nigra L. $1,4,6$ & Black walnut & $\mathrm{N}$ & 2010 & 2 & 29.1 & 11 \\
\hline & & & & & (continue & ext page) \\
\hline
\end{tabular}

\footnotetext{
$\checkmark$ 1, Naturally co-occurring with Ailanthus in forested stands; 2, known species susceptible to Verticillium nonalfalfae according to Schall and Davis (37); 3 , known species; 4, genera; and 5, botanical families containing genera susceptible to $V$. albo-atrum according to Pegg and Brady (32); 6, test species determined by Herrick et al. (17); 7, genera and botanical families closely related to those listed by Herrick et al. (37).

${ }^{w}$ Native status as defined by USDA Natural Resources Conservation Service where N = native and I = introduced. INV and I-W relate to status of plants as defined by the State of Pennsylvania where INV = invasive and I-W = introduced and currently on the state plant watch list.

x Inoculation dates: 2007 = early May 2007; 2009 = late June 2009; $2010=$ early May 2010.

y Single replicate (rep) includes five inoculated plants plus one control plant injected with sterile distilled water.

${ }^{z}$ Locations of inoculation sites throughout south-central Pennsylvania. See Supplementary Fig. 1 and Supplementary Table 2 for site data.
} 
"V. albo-atrum" likely involved V. dahliae, V. nonalfalfae, and/or other Verticillium spp., confounding attempts to accurately assess host ranges of true species. Thus, recent phylogenetic studies have paved the way for comprehensive host range studies for each of the newly recognized species.

Re-examination of pathogenicity is critical, given that some Verticillium species previously reported as pathogenic on certain hosts induced only vascular discoloration, which may or may not be harmful to the plant $(6,10,40)$. This distinction is important for perennial woody plants, since infections may be compartmentalized without the development of outward symptoms (40), or may be transitory even in the presence of wilt, after which plants can resume normal growth with little to no outward symptoms $(13,23)$. In addition, some plant species are asymptomatic hosts, further complicating interpretation of host susceptibility for Verticillium (27). Lastly, the influences of plant age, environment, and seasonality may also play roles in host susceptibility $(14,30,38)$.
The objectives of this study were: i) to evaluate susceptibility of Ailanthus seedlings grown from seed collected from various locations across the United States; ii) to evaluate short- and long-term exposure risk (natural spread) to nontarget species by evaluating incidence of natural infections of $V$. nonalfalfae in forest stands where only Ailanthus had been artificially inoculated from 2006 to 2009; and iii) to evaluate damage incurred (i.e., hazard risk) to nontarget (non-Ailanthus) species through artificial stem inoculations with $V$. nonalfalfae, including native and exotic forest plants.

\section{Materials and Methods}

Susceptibility of Ailanthus seedlings from various seed sources. Ailanthus seed was collected during 2007 to 2011 from 103 locations in 36 U.S. states and Ontario, Canada. Two seed sources, S020 and HS23, served as positive controls since their susceptibility to $V$. nonalfalfae VnAa140 had been previously published (36). Seeds

Table 1. (continued from previous page)

\begin{tabular}{|c|c|c|c|c|c|c|}
\hline Family, genus, species ${ }^{v}$ & Common name & Status $^{w}$ & Inoculation dates $^{x}$ & No. reps ${ }^{y}$ & DBH (cm) & Loc. $^{\mathbf{z}}$ \\
\hline \multicolumn{7}{|l|}{ Lauraceae } \\
\hline Laurus nobilis L. 5 & Sweet bay & N-US & 2010 & 2 & $<1.0$ & GH \\
\hline Lindera benzoin L. & Northern spicebush & $\mathrm{N}$ & 2010 & 2 & 2.0 & 11 \\
\hline Persea borbonia (L.) Spreng. ${ }^{4}$ & Redbay & N-US & 2010 & 2 & $<1.0$ & GH \\
\hline Sassafras albidum (Nutt.) Nees ${ }^{1,3}$ & Sassafras & $\mathrm{N}$ & 2009,2010 & $1 / 2$ & 7.0/11.1 & 11,18 \\
\hline \multicolumn{7}{|l|}{ Leitneriaceae } \\
\hline Leitneria floridana Chapm. ${ }^{6}$ & Corkwood & N-US & & 2 & 1.3 & GH \\
\hline \multicolumn{7}{|l|}{ Magnoliaceae } \\
\hline Liriodendron tulipifera L. ${ }^{1,3}$ & Tulip-poplar & $\mathrm{N}$ & 2007 & 2 & 44.0 & 15 \\
\hline Magnolia acuminata $\mathrm{L}^{4}$ & Cucumbertree & $\mathrm{N}$ & 2010 & 1 & 23.3 & 12 \\
\hline \multicolumn{7}{|l|}{ Meliaceae } \\
\hline Swietenia mahagoni (L.) Jacq. ${ }^{6}$ & West Indian mahogany & $\mathrm{N}-\mathrm{US}$ & & 1 & 2.6 & GH \\
\hline \multicolumn{7}{|l|}{ Nyssaceae } \\
\hline Nyssa sylvatica Marsh. ${ }^{1,3}$ & Black tupelo & $\mathrm{N}$ & 2009,2010 & $1 / 2$ & $8.1 / 5.5$ & 18 \\
\hline \multicolumn{7}{|l|}{ Oleaceae } \\
\hline Fraxinus americana L. ${ }^{1,3}$ & White ash & $\mathrm{N}$ & 2007 & 2 & 46.1 & 15 \\
\hline \multicolumn{7}{|l|}{ Platanaceae } \\
\hline Platanus occidentalis L. & American sycamore & $\mathrm{N}$ & 2010 & 1 & 16.0 & 21 \\
\hline \multicolumn{7}{|l|}{ Rosaceae } \\
\hline Crataegus sp. Tourn. ex L. & Hawthorn & $\mathrm{N}$ & 2010 & 1 & 3.6 & 2 \\
\hline Malus domestica 4 & Apple 'Rome' & I & 2010 & 2 & $<1.0$ & GH \\
\hline Prunus avium L. ${ }^{1,3}$ & Sweet cherry & $\mathrm{N}$ & 2010 & 2 & 23.0 & 16 \\
\hline Prunus serotina Ehrh. ${ }^{1,4,6}$ & Black cherry & $\mathrm{N}$ & 2010 & 2 & 21.6 & 2 \\
\hline Rosa multiflora Thunb. ${ }^{3}$ & Multiflora rose & INV & 2009 & 2 & $<1$ & 10 \\
\hline \multicolumn{7}{|l|}{ Rutaceae } \\
\hline Phellodendron amurense Rupr. ${ }^{3}$ & Amur corktree & $\mathrm{I}-\mathrm{W}$ & 2010 & 2 & 19.9 & 16 \\
\hline $\begin{array}{l}\text { Tetradium daniellii (Benn.) T.G. } \\
\text { Hartley }^{5}\end{array}$ & Korean evodia & I-W & 2010 & 2 & 13.5 & 16 \\
\hline \multicolumn{7}{|l|}{ Salicaceae } \\
\hline Populus alba L. ${ }^{4}$ & White poplar & TR-I & 2010 & 2 & 13.4 & 5 \\
\hline Populus grandidentata Michx. ${ }^{4}$ & Bigtooth aspen & $\mathrm{N}$ & 2010 & 2 & 18.1 & 9 \\
\hline \multicolumn{7}{|l|}{ Scrophulariaceae } \\
\hline Paulownia tomentosa (Thunb.) Steud. ${ }^{5}$ & Royal paulownia & INV & 2010 & 2 & 19.6 & 4 \\
\hline \multicolumn{7}{|l|}{ Simaroubaceae } \\
\hline Ailanthus altissima (Mill.) Swingle ${ }^{1,2}$ & Tree-of-heaven & INV & 2007, 2009, 2010 & 3 & $14.0 / 8.6 /-$ & $1-14$ \\
\hline Picramnia pentandra $\mathrm{Sw}_{5}{ }^{5,6}$ & Florida bitterbush & N-US & 2010 & 3 & 1.2 & $\mathrm{GH}$ \\
\hline Simarouba glauca DC. ${ }^{5,6}$ & Tree-of-paradise & N-US & 2010 & 3 & 1.9 & GH \\
\hline \multicolumn{7}{|l|}{ Tiliaceae } \\
\hline Tilia americana L. ${ }^{1,3}$ & American basswood & $\mathrm{N}$ & 2009,2010 & $1 / 2$ & $27.3 / 21.1$ & 12 \\
\hline \multicolumn{7}{|l|}{ Ulmaceae } \\
\hline Celtis occidentalis $\mathrm{L} .{ }^{5}$ & Hackberry & $\mathrm{N}$ & 2010 & 2 & 23.5 & 11 \\
\hline Ulmus americana L. ${ }^{1,3}$ & American elm & $\mathrm{N}$ & 2009,2010 & $1 / 2$ & $17.3 / 21.2$ & 11 \\
\hline Ulmus pumila $\mathrm{L}^{4}$ & Siberian elm & INV & 2010 & 2 & 29.7 & 22 \\
\hline \multicolumn{7}{|l|}{ Gymnosperms } \\
\hline \multicolumn{7}{|l|}{ Cupressaceae } \\
\hline Juniperus virginiana L. 5,6 & Eastern red cedar & $\mathrm{N}$ & 2010 & 2 & 5.9 & 23 \\
\hline Thuja occidentalis L.4,7 & Arborvitae & $\mathrm{N}$ & 2010 & 1 & - & 5 \\
\hline \multicolumn{7}{|l|}{ Pinaceae } \\
\hline Pinus virginiana Mill. ${ }^{6}$ & Virginia pine & $\mathrm{N}$ & 2010 & 2 & 22.5 & 2 \\
\hline
\end{tabular}


from three other Ailanthus species and/or varieties, including A. altissima forma erythrocarpa (Accession No. 695-80), A. vilmoriniana, and $A$. giraldii (both specimens were Accession No. 76-67), were obtained from the Arnold Arboretum (Boston, MA). Seed was airdried for 7 to 14 days, placed in paper bags, and maintained at room temperature. Up to 40 seeds from each seed source were placed in $15.2 \times 25.4 \mathrm{~cm}$ plastic bags containing approximately $600 \mathrm{ml}$ of Sunshine growing mix (Sun Gro Horticulture Canada Ltd., Vancouver, $\mathrm{BC}$, Canada) and $250 \mathrm{ml}$ tap water. Bags were maintained at $1.7^{\circ} \mathrm{C}$ for 21 to 28 days, after which the seeds were transferred to a greenhouse and placed into seed flats containing Sunshine growing mix and maintained in transparent bags to encourage germination. Following germination, 10 seedlings from each seed source were transplanted into 72-well plug trays $(3.75 \mathrm{~cm}$ diameter $\times 7.50 \mathrm{~cm}$ deep) (T.O. Plastics Inc., Clearwater, MN) and grown for 20 to 30 days.

$V$. nonalfalfae isolate VnAa140 inoculum was prepared as previously described $(25,36)$ and adjusted to $1 \times 10^{7}$ conidia $\mathrm{ml}^{-1}$. Inoculation of seedlings was conducted using a root dip method $(25,33)$. Healthy roots were suspended in inoculum for approximately $10 \mathrm{~s}$ until roots were adequately saturated. Following inoculation, an average of nine seedlings/seed source were individually transplanted into $13 \times 13 \mathrm{~cm}$ plastic pots, and $1 \mathrm{ml}$ of additional inoculum suspension pipetted onto the base of each stem (25). Disease severity was evaluated weekly for 11 weeks, using an ordinal rating system, where $1=$ asymptomatic foliage, $2=$ general marginal leaf chlorosis or necrosis, $3=$ presence of wilt, and $4=$ death. Incidence of chlorosis, necrosis, and/or wilt was also recorded to the nearest $5 \%$ rating interval (25). Plants that exhibited symptoms or died within $36 \mathrm{~h}$ of transplant were discarded since symptoms were attributed to transplanting shock. Prior to senescence, a subset of symptomatic seedlings were randomly selected across the various seed sources; tissues were excised and examined for vascular discoloration. Symptomatic tissues were plated onto plum extract agar (PEA) (44) amended with streptomycin sulfate and neomycin sulfate $(\mathrm{PEA}+\mathrm{SN})$ for detection of $V$. nonalfalfae (25). Upon termination of the experiment, all remaining live plants including controls were destructively sampled and examined for vascular discoloration. Samples from plants that exhibited vascular discoloration were plated onto PEA+SN and the resulting cultures were examined for $V$. nonalfalfae.

Incidence of natural infections by $V$. nonalfalfae on nontarget species within Ailanthus-inoculated forest stands. Beginning in 2009, we evaluated wilt symptoms and mortality on all non-Ailanthus woody perennial plant species growing within artificially-inoculated forest plots, in which 5 to 20 Ailanthus stems had been inoculated 1 to 3 years previously (25). At the time of evaluation, some diseased Ailanthus stands had enlarged to $>30$ ha and contained thousands of dead and dying Ailanthus, thereby providing an opportunity to evaluate exposure risk to co-occurring species. All woody plant species $>2.5 \mathrm{~cm}$ diameter at breast height $(1.4 \mathrm{~m}, \mathrm{DBH})$ within the infected Ailanthus stands were tallied by species and evaluated using a rating system of 0 to 2 , where $0=$ healthy, $1=$ wilted, and $2=$ dead (37). Tissue samples from non-Ailanthus trees exhibiting wilt were removed, returned to the laboratory, and plated on PEA+SN. If present, $V$. nonalfalfae was identified using previously described morphological and molecular techniques (25).

Interspecific host range testing. Field inoculation study area. The general study area was previously described $(25,37)$ and individual stand histories documented (23). Additional host range study sites were established within three Pennsylvania Department of Transportation (PennDOT) right-of-ways and on several new public sites (Supplementary Fig. 1, Supplementary Table 2).

Species selection and stand criteria for nontarget species inoculations. To help prioritize species selection for host range testing, we focused on cohort tree and woody shrub species in several stands that grew intermingled with dead and dying Ailanthus. Selected stands were those where Ailanthus had been artificially inoculated with $V$. nonalfalfae from 2006 to 2009. In addition, stands were also selected that had not been inoculated, but were in the same general areas as the artificially inoculated stands. These criteria resulted in evaluation of 32 nontarget (non-Ailanthus) species (Table 1).
In addition to co-occurring species, we included 54 species previously reported as susceptible to " $V$. albo-atrum" as well as their close relatives (Table 1). This included 22 plant species previously reported as susceptible to " $V$. albo-atrum" and/or $V$. nonalfalfae, as well as 32 additional plant species representing close botanical relatives to species previously reported as susceptible (Table 1). Additionally, we selected 13 non-Ailanthus species that Herrick et al. (17) evaluated for insect susceptibility (Table 1). Previous studies had validated the use of phylogenetic relatedness among plants as a useful metric for species selection in plant pathogenhost range interaction studies (12), thus supporting our decision to test Ailanthus' closest North American relatives. Finally, we included 15 additional exotic plant species known to occur in Pennsylvania, to determine if VnAa140 might be pathogenic on other invasive species.

In total, 72 species, including Ailanthus, were inoculated with V. nonalfalfae VnAa140 between May 2007 and July 2010. Inoculations were conducted in the field, as well as on potted seedlings and saplings in the greenhouse.

Re-evaluation of 2007 field inoculations conducted on nontarget species. Schall and Davis (37) evaluated susceptibility of seven nontarget species to $V$. nonalfalfae for up to 12 months after inoculation. For the purposes of longer term investigations, these same trees were re-evaluated in 2009, 2011, and 2013 for the presence of wilt and/or mortality, thus providing a $>6$-year postinoculation dataset. In May 2009 and May 2011, sites were revisited to evaluate symptoms and assign disease ratings to trees inoculated in 2007. A similar rating system as described previously for Ailanthus seed sources was utilized. In July 2011, the same trees were evaluated for vascular discoloration, which had not been evaluated previously. The presence or absence of vascular discoloration was recorded at the inoculation point of inoculated trees, and at the wound on control trees, by removing adjacent bark and surface wood with a surface-disinfested hatchet. On larger trees, radial increment cores were also extracted at approximately $1 \mathrm{~m}$ above the inoculation point using a Haglof increment borer (Haglof Inc., Madison, MS). If vascular discoloration was not observed on the increment core in the field, a second increment core was removed from $1 \mathrm{~m}$ above a second inoculation point on the same tree (each tree had been inoculated at three points). Cores were taken to the lab, mounted, sanded, and prepared as described by Kasson et al. (23), after which cores were examined for evidence of vascular occlusion.

Field inoculations of nontarget species in 2009 to 2010. Field inoculation sites were selected based on incidence and density of nonAilanthus species, co-occurrence with Ailanthus, and site accessibility. At least two replicates were selected for most species, each replicate consisting of five inoculated stems and one water-inoculated control. For less abundant nontarget species, inoculations in more than one stand were necessary to meet the desired number of inoculated stems (Table 1). For more scarce species, only one replicate per species could be established (Table 1).

In late June 2009, nine native tree species and four exotic plant species were selected across six sites (Table 1). All 13 species had been reported as susceptible to " $V$. albo-atrum" (32). Inoculum was $1 \times 10^{7}$ conidia $\mathrm{ml}^{-1}$ and was prepared as previously described (25). Five plants of each species were stem injected with VnAa140 either using a hypo-hatchet (OEM Fabricators Inc., Woodville, WI) for trees, or a syringe for small trees and shrubs that delivered $1 \mathrm{ml}$ conidia suspended in sterile distilled water per injection $(25,36)$. The volume of inoculum delivered depended on stem diameter, with plants $>7.6 \mathrm{~cm}$ diameter receiving $3 \mathrm{ml} / \mathrm{stem}$, plants 2.5 to $7.6 \mathrm{~cm}$ diameter receiving $2 \mathrm{ml} / \mathrm{stem}$, and plants $<2.5 \mathrm{~cm}$ diameter receiving $1 \mathrm{ml} / \mathrm{stem}$. One additional plant per replicate was wounded and treated with sterile distilled water as a control.

Disease severity (ratings, \% incidence of wilt, defoliation) of 2009 inoculated plants was evaluated biweekly through September 2009, at which time inoculated plants and controls were examined for the presence of vascular discoloration.

Based on the 2009 results, 11 of 13 species tested were included in a more extensive early-season 2010 host range study. In early May 
2010, the 11 aforementioned species, 32 additional native species, and 17 additional non-native plant species including Ailanthus were inoculated with $V$. nonalfalfae isolate VnAa140 as previously described (Table 1). Both Ailanthus and striped maple served as positive controls $(25,36,37)$. Disease severity (ratings, \% incidence of wilt, defoliation) of 2010 inoculated plants was evaluated biweekly through August 2010, at which time inoculated plants and controls were examined for the presence of vascular discoloration. Evaluation of plants resumed in May 2011 and continued monthly until late August 2011. Tissue samples were removed from trees exhibiting vascular discoloration, plated on PEA+SN, and examined for $V$. nonalfalfae based on morphology.

2010 Greenhouse inoculations of potted nontarget species. Eight plant species, including seven native species whose geographic range was outside Pennsylvania and one non-native cultivated fruit tree species, were inoculated with $V$. nonalfalfae isolate VnAa140 to assess susceptibility (Table 2). Florida bitterbush (Picramnia pentandra Sw.) and tree-of-paradise (Simarouba glauca DC.) were selected since they are members of the Simaroubaceae family, which includes $A i$ lanthus, and represent the closest North American relatives of Ailanthus (17). Two additional native species, corkwood (Leitneria floridana Chapm.) and West Indian mahogany (Swietenia mahagoni (L.) Jacq.), were selected since they are members of the families Leitneriaceae and Meliaceae, respectively, which are closely related to Simaroubaceae (17). Four additional species including domesticated apple (Malus domestica Borkh. 'Rome'), crossvine (Bignonia capreolata L.), redbay (Persea borbonia (L.) Spreng.), and bay laurel (Laurus nobilis L.) were selected for inoculation. The latter three species are closely related to northern catalpa and sassafras, both of which were classified as susceptible hosts to VnAa140 following 2009 inoculations. Apple was chosen on account of previously reported susceptibility of Malus sp. to Verticillium wilt (32).

Plants were purchased in June 2010 from two commercial native tree nurseries (Forest Farms Nursery, Williams, OR, and Kelly's Tropicals, Homestead, FL). All plants were transplanted into plastic pots containing Sunshine growing mix, fertilized once with Osmocote, a 12:12:12 $\mathrm{N}: \mathrm{P}_{2} \mathrm{O}_{3}: \mathrm{K}_{2} \mathrm{O}$ slow release fertilizer (Scotts MiracleGro, Marysville, $\mathrm{OH}$ ), and maintained in a greenhouse for 3 weeks prior to inoculation. After 3 weeks, healthy plants were inoculated with $V$. nonalfalfae VnAa140 into three scalpel wounds on the lower third of the stem using a syringe that delivered $1 \mathrm{ml}$ of $1 \times 10^{7}$ conidia $\mathrm{ml}^{-1}$ per injection (25). Plants were $\leq 2.5 \mathrm{~cm}$ diameter (Table 1). One tree of each species within each replication was inoculated with sterile distilled water and served as a control. Inoculated plants were examined weekly for 9 weeks. Weekly disease severity ratings (1 to 4 ) were assigned to each plant (25). Since potted greenhouse seedlings were shorter than the field plants, incidence of vascular discoloration was recorded at one-third total plant height above the inoculation point for all inoculated and control plants. Tissue samples were removed from stems exhibiting vascular discoloration and plated onto PEA+SN. $V$. nonalfalfae was identified using morphological and molecular techniques.

Table 2. Incidence of wilt of nontarget species in Ailanthus-inoculated forest stands in south-central Pennsylvania

\begin{tabular}{|c|c|c|c|c|c|c|c|c|c|c|}
\hline \multirow[b]{2}{*}{ Species } & \multicolumn{3}{|c|}{15 MPI $(n=10)^{y}$} & \multicolumn{3}{|c|}{39 MPI $(n=4)$} & \multicolumn{3}{|c|}{$63 \operatorname{MPI}(n=1)$} & \multirow[b]{2}{*}{ Mean disease rating } \\
\hline & $\mathbf{H}^{\mathbf{z}}$ & $\mathrm{W}(\%)$ & $\mathrm{D}(\%)$ & $\mathbf{H}$ & $\mathrm{W}(\%)$ & D $(\%)$ & $\mathbf{H}$ & $\mathrm{W}(\%)$ & $\mathrm{D}(\%)$ & \\
\hline Ailanthus $^{\mathrm{w}}$ & 0 & $1,039(58)$ & $749(42)$ & 0 & $4,318(68)$ & $2,026(32)$ & 0 & 6,234 & 2,663 & $1.346 \mathrm{a}$ \\
\hline Black locust & 100 & 0 & $170(63)$ & 261 & 0 & $519(67)$ & 436 & 0 & $447(51)$ & $1.201 \mathrm{a}$ \\
\hline Devil's walkingstickw & 13 & $4(22)$ & 0 & 4 & $1(13)$ & $3(38)$ & - & - & - & $0.555 \mathrm{~b}$ \\
\hline Staghorn sumac & 22 & $7(24)$ & 0 & 30 & $4(8)$ & $14(29)$ & - & - & - & $0.454 \mathrm{bc}$ \\
\hline Boxelder & - & - & - & 4 & 0 & 0 & - & - & - & $0.000 \mathrm{c}$ \\
\hline Sassafras & 26 & 0 & 0 & 25 & 0 & $5(17)$ & - & - & - & $0.333 \mathrm{bc}$ \\
\hline Striped maple ${ }^{\mathrm{w}}$ & 86 & $6(6)$ & $6(6)$ & 868 & $5(1)$ & $62(7)$ & 1,477 & $32(2)$ & $258(15)$ & $0.211 b c$ \\
\hline Norway maple & 2 & 0 & 0 & 4 & 0 & 0 & - & - & - & $0.000 \mathrm{c}$ \\
\hline Autumn olive & 29 & 0 & 0 & - & - & - & - & - & - & $0.000 \mathrm{bc}$ \\
\hline Eastern redbud & 10 & 0 & 0 & - & - & - & - & - & - & $0.000 \mathrm{bc}$ \\
\hline Flowering dogwood & 26 & $1(3)$ & $3(10)$ & 5 & 0 & 0 & 4 & 0 & 0 & $0.233 \mathrm{bc}$ \\
\hline Hophornbeam & 8 & $2(20)$ & 0 & 2 & 0 & 0 & 11 & 0 & 0 & $0.200 \mathrm{bc}$ \\
\hline Black cherry & 28 & 0 & 0 & 222 & 0 & $17(7)$ & 19 & 0 & 0 & $0.142 \mathrm{bc}$ \\
\hline Royal paulownia & 5 & 0 & 0 & 14 & 0 & 0 & 14 & 0 & $1(7)$ & $0.133 \mathrm{bc}$ \\
\hline Sugar maple & 41 & 0 & $2(5)$ & 4 & 0 & 0 & 14 & 0 & 0 & $0.093 \mathrm{bc}$ \\
\hline American elm & 98 & 0 & $1(1)$ & 88 & 0 & $12(12)$ & 25 & 0 & 0 & $0.087 \mathrm{c}$ \\
\hline Black birch & 115 & 0 & $10(8)$ & 464 & 0 & $12(3)$ & 550 & $1(0)$ & $17(3)$ & $0.083 \mathrm{bc}$ \\
\hline Red oak & 13 & 0 & 0 & 26 & 0 & $1(4)$ & 6 & 0 & 0 & $0.074 \mathrm{bc}$ \\
\hline Black walnut & 71 & $1(1)$ & $2(3)$ & 24 & 0 & 0 & - & - & - & $0.068 \mathrm{bc}$ \\
\hline Red maple & 139 & 0 & $10(7)$ & 322 & 0 & $4(1)$ & 376 & $1(0)$ & $14(4)$ & $0.067 \mathrm{c}$ \\
\hline Hickory & 178 & 0 & 0 & 211 & 0 & 0 & 59 & 0 & $2(3)$ & $0.066 \mathrm{bc}$ \\
\hline Black oak & - & - & - & 36 & 0 & $1(3)$ & 4 & 0 & 0 & $0.054 \mathrm{bc}$ \\
\hline Witch-hazel & 86 & 0 & 0 & 787 & 0 & $15(2)$ & 1,118 & $1(0)$ & $36(3)$ & $0.050 \mathrm{bc}$ \\
\hline American basswood & 204 & $2(1)$ & 0 & 205 & $2(1)$ & $2(1)$ & 242 & 0 & 0 & $0.019 \mathrm{c}$ \\
\hline Tulip-poplar & 537 & 0 & $4(1)$ & 970 & 0 & $8(1)$ & 16 & 0 & 0 & $0.016 \mathrm{c}$ \\
\hline Ash & 53 & 0 & 0 & 12 & 0 & 0 & 32 & 0 & 0 & $0.000 \mathrm{c}$ \\
\hline Northern spicebush & 37 & 0 & 0 & 220 & 0 & 0 & 3 & 0 & 0 & $0.000 \mathrm{c}$ \\
\hline Black tupelo & 6 & 0 & 0 & 1 & 0 & 0 & 2 & 0 & 0 & $0.000 \mathrm{c}$ \\
\hline Chestnut oak & 47 & 0 & 0 & 20 & 0 & 0 & 15 & 0 & 0 & $0.000 \mathrm{c}$ \\
\hline Other ${ }^{x}$ & 8 & 0 & 0 & 19 & 0 & 0 & 2 & 0 & 0 & $0.000 \mathrm{c}$ \\
\hline
\end{tabular}

${ }^{\mathrm{w}}$ Susceptible to Verticillium nonalfalfae based on wilt, vascular discoloration, reisolation, and mortality following natural spread from infected Ailanthus. Previous isolations from Ailanthus, devil's walkingstick, and striped maple confirmed the presence of $V$. nonalfalfae.

$x$ 'Other' designation includes species that represented $<1 \%$ of the total stems tallied for a single species and exhibited no wilt or mortality. Species included Carpinus carolinia, Catalpa speciosa, Celtis occidentalis, Fagus grandifolia, Gleditsia triacanthos, Morus alba, Prunus avium, Prunus pensylvanicum, Quercus alba, and Viburnum prunifolium.

y MPI, months postinoculation ( $n=$ plot sample size). Sites sampled were as follows: 15 MPI, 10 2008-inoculated stands (BSF1-2; MSF1, 3-5; RLK1-3, SGL1) and one 2009-inoculated site (CCSP); 39 MPI, one 2006-inoculated site (TSF-BM), BSF2, RLK1, and SGL1; 63 MPI, TSF-BM; 84 MPI, initial TSF epicenter where disease first appeared in 2000.

${ }^{\mathrm{z}}$ For no. of trees, $\mathrm{H}$ is the no. of healthy trees, $\mathrm{W}$ is no. of wilted trees followed by percent of the total, and $\mathrm{D}$ is the no. of dead trees followed by percent of the total. 
Statistical analyses. Differences in disease severity values among Ailanthus seed sources and field and greenhouse inoculated plant species were evaluated at the end of each experiment by direct comparisons of mean area under the disease progress curve (AUDPC) (37) values using analysis of variance (ANOVA). Differences in disease severity values among naturally infected nontarget plant species was evaluated using previously described methods $(35,37)$. Tukey's mean comparisons were used to detect significant differences among treatments and between inoculated plants and controls. All analyses were conducted using the statistical software program Minitab 16.1.0 (Minitab Inc., State College, PA).

\section{Results}

Susceptibility of Ailanthus seedlings from various seed sources. Seventy-eight of the 104 Ailanthus seed sources from 26 states and one
Canadian province had viable seed that germinated and produced seedlings. Of 649 total seedlings included in the study across all 78 seed sources, 635 showed susceptibility to $V$. nonalfalfae VnAa140 within the 11-week experiment (Fig. 1). Initial symptoms including wilt, chlorosis, defoliation, and sprouting that developed within 3 weeks after inoculation (Fig. 2). Differences among AUDPC means were significant. AUDPC values for the two positive controls [S020 (36.5) and HS23 (34.9)] had the first and fifth highest AUDPC means, which were significantly greater than 18 and 11 seed sources, respectively. The AUDPC values for all inoculated Ailanthus seed sources were significantly different from the noninoculated controls $(P=0.01)$ (Supplementary Table 1).

Of the 649 inoculated Ailanthus seedlings, 14 individuals from 11 seed sources did not exhibit disease symptoms by the end of the experiment (11 weeks postinoculation, Fig. 1) even though most susceptible individuals developed symptoms within 3 weeks of

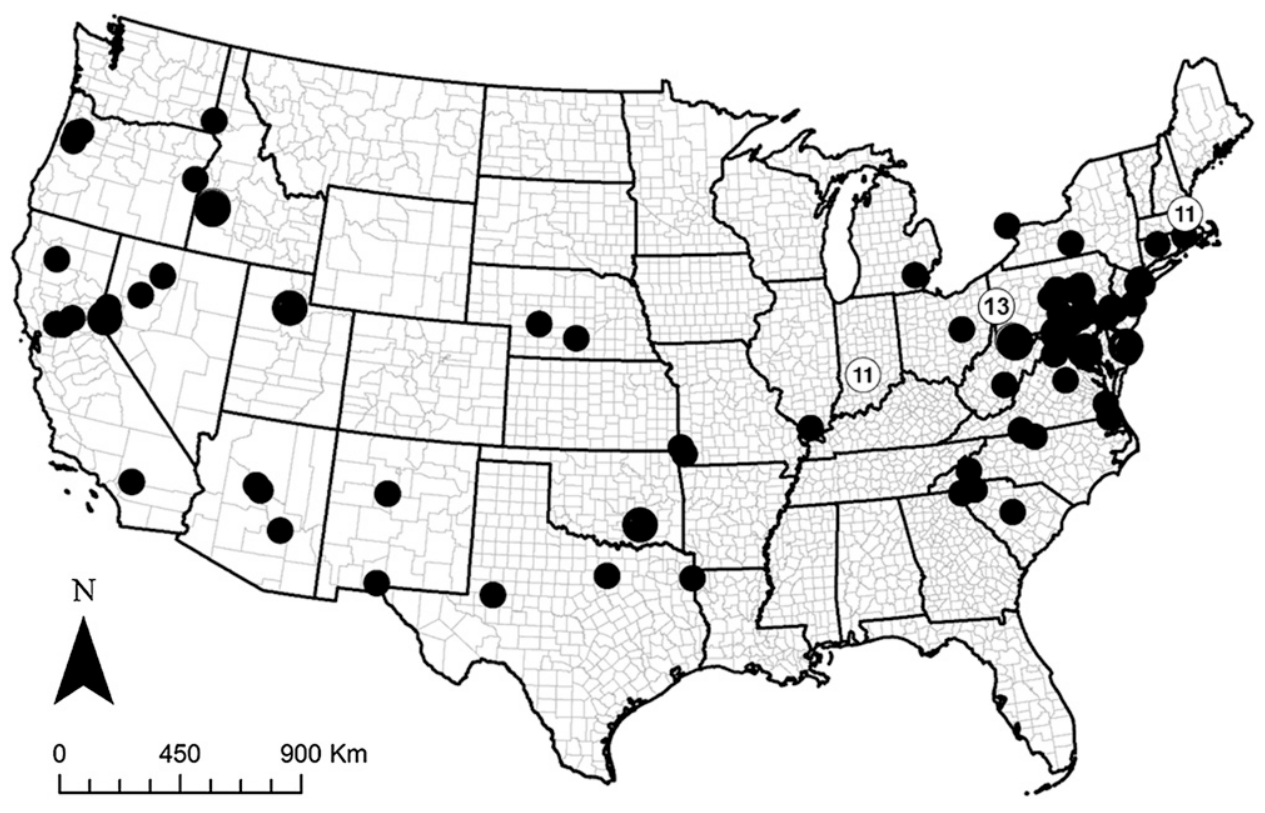

Fig. 1. Origin and susceptibility status of greenhouse grown seedlings from U.S. and Canadian Ailanthus seed sources challenged with Verticillium nonalfalfae isolate VnAa140. Black circles denote fully susceptible seed sources, white circles with numbers inside circles indicate seed sources with reduced diseases incidence at 11 weeks postinoculation. Numbers indicate the percentage of asymptomatic individuals within a single seed source. See Supplementary Table 1 for specific locations, date of collection, collectors, and sample size.
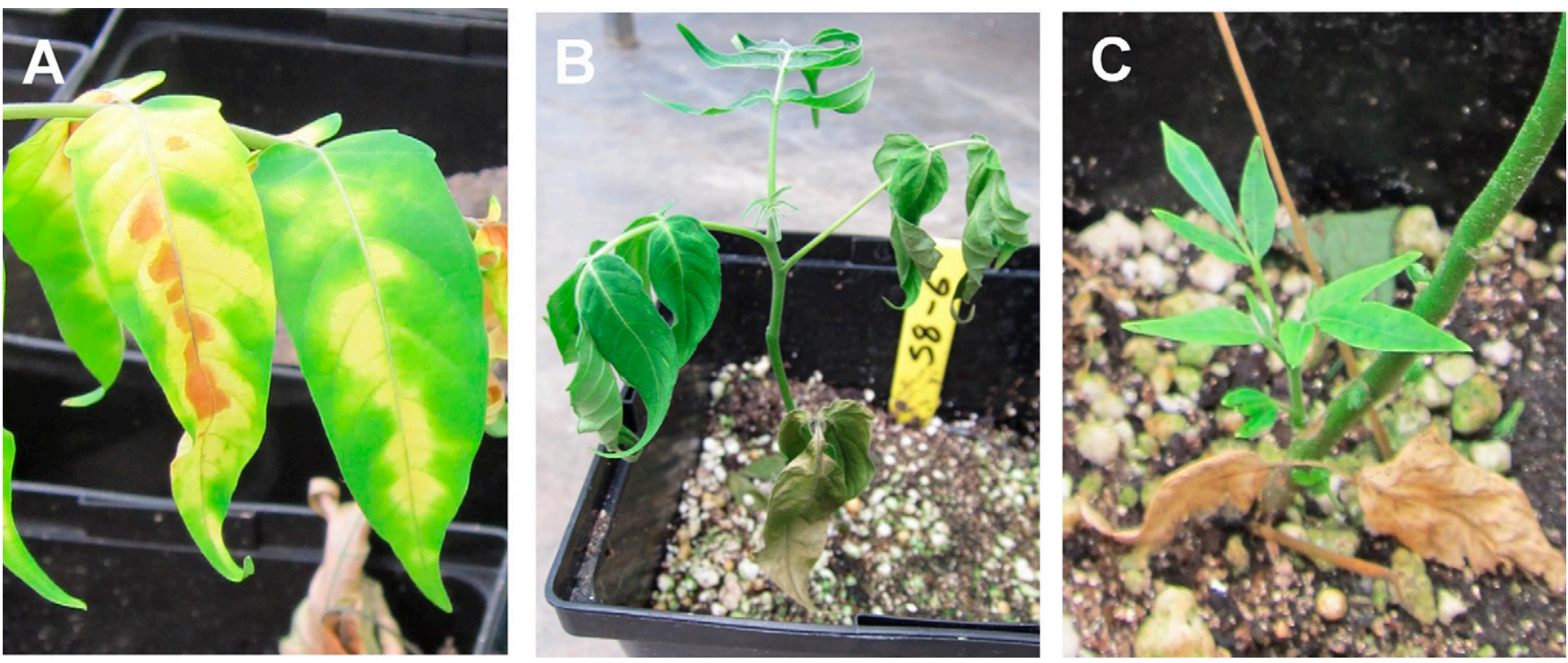

Fig. 2. Verticillium wilt symptoms of greenhouse grown Ailanthus used in intraspecific resistance screening such as A, leaflet chlorosis and necrosis, B, acute foliar wilt, and C, basal sprouting following wilt of primary foliage in potted Ailanthus seedlings between 4 and 7 weeks postinoculation. 
inoculation. Seed sources containing one or more asymptomatic individuals were from western Pennsylvania (P066), two locations in West Virginia (S004 and S009), Delaware (S085), Idaho (S092), Massachusetts (S018), Maryland (S011), Nevada (S134), Oklahoma (S104), Utah (S110), and Indiana (S028) (Fig. 1).

Vascular discoloration was observed in all diseased individuals and six of 14 asymptomatic individuals including P066 (two seedlings), S009, S018, S028, and S092. Vascular discoloration was absent from all sampled controls. However, vascular discoloration was localized to a few xylem vessels in S009, S092, and one of two P066 seedlings. $V$. nonalfalfae was reisolated on PEA+SN from only three asymptomatic seedlings (from seed sources S018, S028, and P066), suggesting that infections developed more slowly in these individuals. Destructive sampling of asymptomatic seedlings from Nevada, Utah, Oklahoma, Maryland, Delaware, and one of two West Virginia seed sources revealed no vascular discoloration and yielded no $V$. nonalfalfae, which likely suggests inoculation failure for these individuals.

Incidence of natural infections by $V$. nonalfalfae on nontarget species within Ailanthus-inoculated forest stands. Natural spread of $V$. nonalfalfae from diseased Ailanthus to nontarget hosts was confirmed in two of 38 species examined: devil's walkingstick and striped maple (Table 2). A third species, staghorn sumac, exhibited acute wilt in some branches during the study (Table 2), although $V$. nonalfalfae was not recovered.

Ailanthus (1.346), black locust (1.201), devil's walkingstick (0.555), and staghorn sumac (0.454) had significantly greater disease ratings than other species (Table 2). Mortality of black locust occurred, but was also present in stands with no Verticillium wilt and was attributed to locust borer (Megacyllene robiniae Forster) based on the presence white to yellow boring dust and insect holes as well as knotty swellings on the trunk and top breakage. Moreover, black locust exhibited no wilt or mortality during 2006 through 2011, thus supporting locust borer as a causal agent contributing to the observed mortality. Mean disease ratings for Ailanthus and black locust were not significantly different from each other, but were significantly greater than for all other species $(P=0.0000$, Table 2$)$. Mean disease ratings ( 0.555$)$ for devil's walkingstick were significantly less than Ailanthus (1.346) and black locust (1.201), not significantly different from sumac (0.454), and significantly greater than all other species (Table 2).

Verticillium wilt on devil's walkingstick was observed within two stands where Ailanthus had been artificially inoculated. Wilt symptoms on devil's walkingstick were typical of Verticillium infection, exhibiting chlorotic and wilted leaves throughout the crown and associated vascular discoloration (Fig. 3A). V. nonalfalfae was isolated from the rachis of the compound leaves at both locations and molecularly characterized (25).

Of the 77 staghorn sumacs observed across three observation periods, $11(14 \%)$ exhibited wilt symptoms and $14(18 \%)$ were dead. However, mortality was observed only during the 39 months postinoculation (MPI) rating, not earlier, suggesting atypical disease progression. Nevertheless, $V$. nonalfalfae could not be isolated from symptomatic sumac (Table 2).

Striped maple also was susceptible to infections acquired through the natural spread of $V$. nonalfalfae from diseased Ailanthus (Fig. 3B), although mean disease ratings were not significantly different from other nontarget species that did not exhibit Verticillium wilt symptoms. This is likely related the large number of healthy striped maple recorded across all stands resulting in a relatively low incidence of infected stems across a larger population (Table 2). Nonetheless, $V$. nonalfalfae was isolated from $>6$ symptomatic striped maples across three separate locations. Of the 2,800 striped maples observed during this study, only 43 (1.5\%) were symptomatic (Fig. 3C) and another 326 (11.6\%) were dead, although some of the deaths were attributed to sunscald following rapid overstory mortality based on vertical cracks on the tree trunk, usually on the southwest side. There was a significant increase in striped maple mortality at 63 MPI compared with earlier evaluations at 15 and 39 MPI (Table 3).
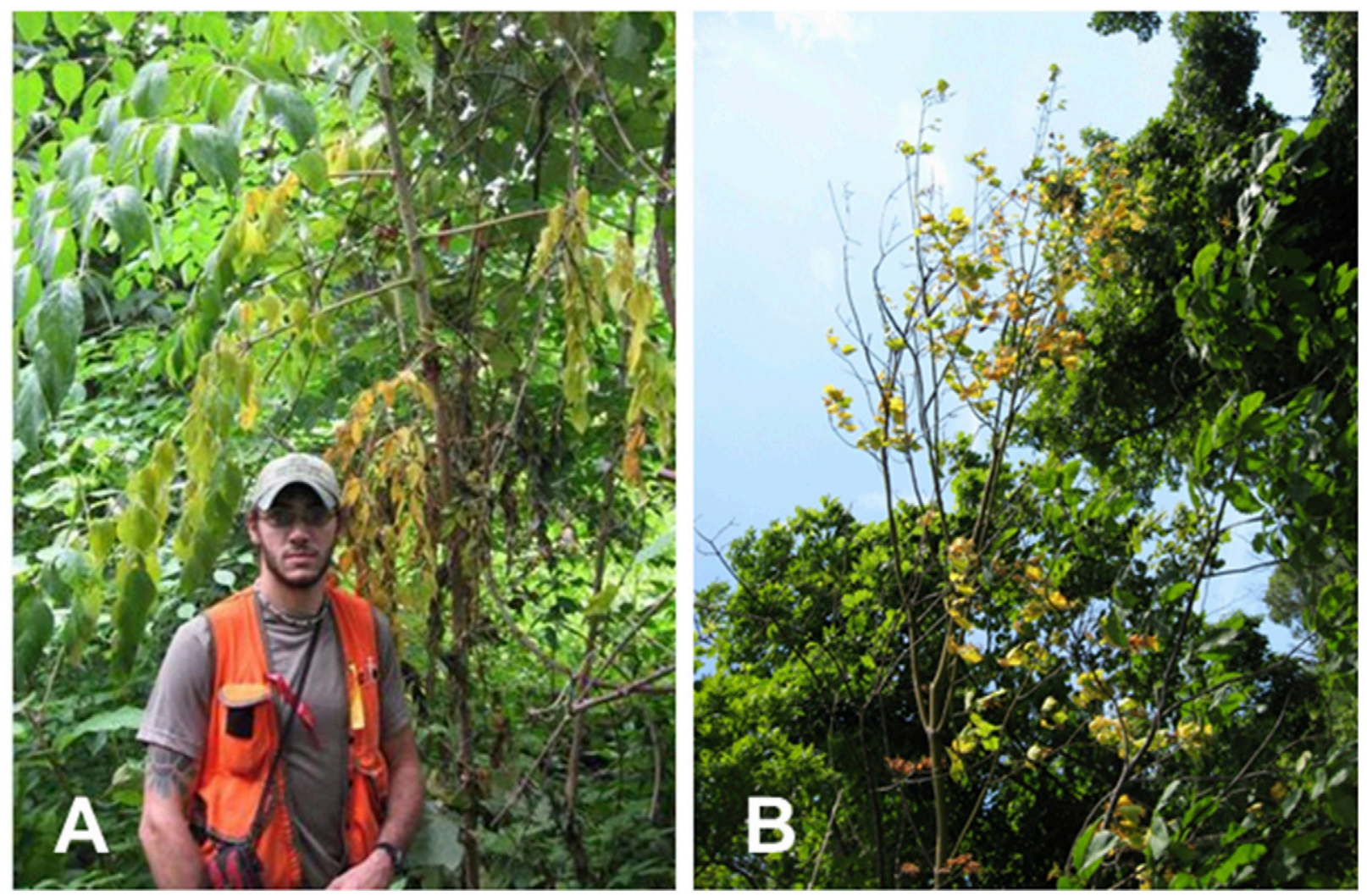

Fig. 3. Acute foliar wilt symptoms associated with natural infections of Verticillium nonalfalfae in A, devil's walkingstick and B, striped maple following artificial inoculation of cooccurring Ailanthus 
Several other tree species, including flowering dogwood, hophornbeam, basswood, black walnut, and witch-hazel included individuals that exhibited limited branch wilt. However, $V$. nonalfalfae could not be isolated from diseased tissues, nor was vascular discoloration observed in the stems (Table 2).

Interspecific host range testing. Re-evaluation of 2007 field inoculations of nontarget species. The first evaluation of AUDPC at 5 MPI for trees inoculated in May 2007 revealed significantly $(P=0.0000)$ greater disease severity ratings for inoculated Ailanthus and striped maple than for all other inoculated species. Mean AUDPC values at 5 MPI for Ailanthus were significantly greater than for striped maple, despite both species dying within 20 weeks of inoculation (September 2007, Table 3). Comparisons of mean AUDPC values at 26 and 49 MPI for these same species revealed significantly greater values for inoculated Ailanthus and striped maple than for all other species and controls $(P=0.0000)$.

In 2011, vascular discoloration was detected in red maple, tulippoplar, red oak, and sugar maple, all of which had been previously listed as nonhosts (37). Vascular discoloration had not been previously evaluated for these 2007-inoculated species. Vascular discoloration was especially pronounced in red maple and tulip-poplar, in which dark staining was also apparent in adjacent sapwood rings but absent from water-inoculated controls (Fig. 4, Supplementary Fig. 2). Vascular discoloration varied in color, as well as longitudinal

Table 3. Susceptibility status, year of inoculation, number of plants examined, plants with wilt symptoms (avg. \% wilt plant ${ }^{-1}$ ), mortality, and vascular discoloration, as well as mean AUDPC values versus controls and Ailanthus for 41 native and exotic tree, shrub, and vine species that exhibited one or more symptoms following stem injection with Verticillium nonalfalfae VnAa140

\begin{tabular}{|c|c|c|c|c|c|c|c|c|c|c|c|c|c|c|c|c|c|c|c|c|c|}
\hline \multirow{3}{*}{$\frac{\text { Species }}{\text { Ailanthus }^{\mathrm{v}}}$} & \multirow{3}{*}{$\begin{array}{l}\text { Status }^{\mathbf{w}} \\
\text { NH-S }\end{array}$} & \multirow{2}{*}{\multicolumn{3}{|c|}{$\begin{array}{c}\text { Inoculation } \\
\text { dates }\end{array}$}} & \multirow{2}{*}{\multicolumn{3}{|c|}{$\begin{array}{l}\text { Number } \\
\text { inoculated }\end{array}$}} & \multicolumn{8}{|c|}{ Total number of trees } & \multicolumn{6}{|c|}{ Mean AUDPC value } \\
\hline & & & & & & & & \multicolumn{2}{|c|}{ Wilted (\% wilt) } & \multicolumn{3}{|c|}{$\operatorname{Died}^{x}$} & \multicolumn{3}{|c|}{$\begin{array}{c}\text { With } \\
\text { vascular } \\
\text { discol- } \\
\text { orationy }\end{array}$} & \multicolumn{3}{|c|}{$\begin{array}{l}\text { Versus } \\
\text { control }\end{array}$} & \multicolumn{3}{|c|}{$\begin{array}{c}\text { Versus } \\
\text { Ailanthus }\end{array}$} \\
\hline & & 2007 & 2009 & 2010 & 10 & 20 & 15 & 10 & 15 (all 100) & 10 & 20 & 15 & - & 20 & 15 & $\mathrm{sd}$ & $\mathrm{sd}$ & sd & - & - & - \\
\hline Striped maplev & NH-S & 2007 & - & 2010 & 15 & - & 5 & $15(100)$ & $5(100)$ & 15 & - & 5 & $?$ & - & 4 & sd & - & sd & sd & - & - \\
\hline Autumn olive & $\mathrm{S}$ & - & - & 2010 & - & - & 10 & $7(48)$ & & - & - & $2 *$ & - & - & 10 & - & - & - & - & - & $\mathrm{sd}$ \\
\hline Black locust & $\mathrm{S}$ & - & 2009 & 2010 & - & 5 & 10 & $1(35)$ & $8(75)$ & - & 0 & 1 & - & 0 & 10 & - & - & - & - & sd & $\mathrm{sd}$ \\
\hline Corkwood & $\mathrm{S}$ & - & - & 2010 & - & - & 10 & $10(54)$ & & - & - & 3 & - & - & 10 & - & - & sd & $\mathrm{n} / \mathrm{a}$ & & \\
\hline Eastern redbud & $\mathrm{S}$ & - & 2009 & 2010 & - & 5 & 10 & $1(20)$ & $6(21)$ & - & 0 & 2 & - & 5 & 10 & - & - & - & - & sd & $\mathrm{sd}$ \\
\hline Japanese maple & $\mathrm{S}$ & - & 2009 & 2010 & - & 5 & 9 & 0 & $4(13)$ & - & 1 & 3 & - & 5 & 5 & - & - & - & - & sd & $\mathrm{su}$ \\
\hline Northern catalpa & $\mathrm{S}$ & - & 2009 & 2010 & - & 5 & 10 & $5(64)$ & $10(60)$ & - & 1 & 0 & - & 5 & 9 & - & $\mathrm{sd}$ & - & - & - & $\mathrm{sd}$ \\
\hline Norway maple & $\mathrm{S}$ & - & - & 2010 & - & - & 10 & $6(17)$ & & - & - & 2 & - & - & 10 & - & - & - & - & - & $\mathrm{sd}$ \\
\hline Sassafras & $\mathrm{S}$ & - & 2009 & 2010 & - & 5 & 9 & $5(80)$ & $9(77)$ & - & 1 & 2 & - & 5 & 10 & - & $\mathrm{sd}$ & - & & sd & $\mathrm{sd}$ \\
\hline Staghorn sumac & PS & - & 2009 & 2010 & - & 5 & 10 & 0 & $10(100)$ & - & 0 & 9 & - & 1 & 10 & - & - & sd & - & sd & - \\
\hline Amur corktree & PS & - & - & 2010 & - & - & 10 & $10(63)$ & & - & - & 2 & - & - & 7 & - & - & - & - & - & $\mathrm{sd}$ \\
\hline Angelica tree & PS & - & - & 2010 & - & - & 10 & $9(41)$ & & - & - & $1 *$ & - & - & 8 & - & - & - & - & - & 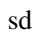 \\
\hline Crossvine & PS & - & - & 2010 & - & - & 10 & $3(20)$ & & - & - & 0 & - & - & 10 & - & - & sd & $\mathrm{n} / \mathrm{a}$ & & \\
\hline Northern spicebush & PS & - & - & 2010 & - & - & 10 & $1(10)$ & & - & - & 1 & - & - & 4 & - & - & - & - & - & $\mathrm{sd}$ \\
\hline Poison-ivy & PS & - & - & 2010 & - & - & 10 & $10(100)$ & & - & - & 10 & - & - & 10 & - & - & sd & - & - & - \\
\hline Redbay & PS & - & - & 2010 & - & - & 10 & $2(10)$ & & - & - & 0 & - & - & 10 & - & - & - & $\mathrm{n} / \mathrm{a}$ & & \\
\hline Red elderberry & PS & - & - & 2010 & - & - & 9 & $8(78)$ & & - & - & $7 *$ & - & - & 0 & - & - & sd & - & - & - \\
\hline Korean evodia & $\mathrm{T}$ & - & - & 2010 & - & - & 10 & 0 & & - & - & 0 & - & - & 9 & - & - & - & - & - & $\mathrm{sd}$ \\
\hline Red maple & $\mathrm{T}$ & 2007 & - & - & 15 & - & - & 0 & & $1 \#$ & - & - & 5 & - & - & - & - & - & $\mathrm{sd}$ & - & - \\
\hline Sugar maple & $\mathrm{T}$ & 2007 & - & - & 10 & - & - & 0 & & $1 \#$ & - & - & 3 & - & - & - & - & - & $\mathrm{sd}$ & - & - \\
\hline Tree-of-paradise & $\mathrm{T}$ & - & - & 2010 & - & - & 15 & $8(16)$ & & - & - & 0 & - & - & 13 & - & - & - & $\mathrm{n} / \mathrm{a}$ & & \\
\hline American basswood & $\mathrm{R}$ & - & 2009 & 2010 & - & 5 & 10 & 0 & & - & 0 & 0 & - & 5 & 9 & - & - & - & - & sd & \\
\hline American chestnut & $\mathrm{R}$ & - & - & 2010 & - & - & 10 & 10 & & - & - & $9 \#$ & - & - & 0 & $\mathrm{n} / \mathrm{a}$ & & & $\mathrm{n} / \mathrm{a}$ & & \\
\hline American elm & $\mathrm{R}$ & - & 2009 & 2010 & - & 5 & 9 & 0 & & - & 0 & 0 & - & 5 & 9 & - & - & - & - & sd & $\mathrm{sd}$ \\
\hline Black birch & $\mathrm{R}$ & - & - & 2010 & - & - & 10 & $1(20)$ & & - & - & $1 \#$ & - & - & 0 & - & - & - & - & - & $\mathrm{su}$ \\
\hline Black cherry & $\mathrm{R}$ & - & - & 2010 & - & - & 10 & 0 & & - & - & 0 & - & - & 9 & - & - & - & - & - & \\
\hline Black tupelo & $\mathrm{R}$ & - & 2009 & 2010 & - & 5 & 10 & 0 & & - & 0 & 0 & - & 0 & 5 & - & - & - & - & sd & \\
\hline Black walnut & $\mathrm{R}$ & - & - & 2010 & - & - & 8 & 0 & & - & - & 0 & - & - & 3 & - & - & - & - & - & so \\
\hline Cucumbertree & $\mathrm{R}$ & - & - & 2010 & - & - & 5 & 0 & & - & - & $1 *$ & - & - & 5 & - & - & - & - & - & \\
\hline Florida bitterbush & $\mathrm{R}$ & - & - & 2010 & - & - & 15 & 0 & & - & - & 0 & - & - & 5 & - & - & - & $\mathrm{n} / \mathrm{a}$ & & \\
\hline Hackberry & $\mathrm{R}$ & - & - & 2010 & - & - & 10 & 0 & & - & - & 0 & - & - & 10 & - & - & - & - & - & Sc \\
\hline Honey locust & $\mathrm{R}$ & - & - & 2010 & - & - & 5 & 0 & & - & - & 0 & - & - & 4 & - & - & - & - & - & \\
\hline Hophornbeam & $\mathrm{R}$ & - & - & 2010 & - & - & 10 & 0 & & - & - & 0 & - & - & 9 & - & - & - & - & - & se \\
\hline Japanese barberry & $\mathrm{R}$ & - & 2009 & - & - & 5 & - & 0 & & - & 0 & - & - & 3 & - & - & - & - & - & $\mathrm{sd}$ & - \\
\hline Northern red oak & $\mathrm{R}$ & 2007 & - & - & 10 & - & - & 0 & & $1 \#$ & - & - & 2 & - & - & - & - & - & $\mathrm{sd}$ & - & - \\
\hline Pawpaw & $\mathrm{R}$ & - & - & 2010 & - & - & 10 & 0 & & - & - & 1 & - & - & 10 & - & - & - & - & - & $\mathrm{SC}$ \\
\hline Persian silktree & $\mathrm{R}$ & - & - & 2010 & - & - & 10 & 0 & & $1 \#$ & - & - & - & - & 2 & - & - & - & - & - & $\mathrm{sd}$ \\
\hline Siberian elm & $\mathrm{R}$ & - & - & 2010 & - & - & 10 & 0 & & - & - & 0 & - & - & 4 & - & - & - & - & - & \\
\hline Sweet cherry & $\mathrm{R}$ & - & - & 2010 & - & - & 10 & 0 & & - & - & 0 & - & - & 4 & - & - & - & - & - & $\mathrm{su}$ \\
\hline Tulip-poplar & $\mathrm{R}$ & 2007 & - & - & 10 & - & - & 0 & & 0 & - & - & 6 & - & - & - & - & - & $\mathrm{sd}$ & - & \\
\hline
\end{tabular}

v Susceptible to $V$. nonalfalfae based on wilt, vascular discoloration, and mortality following natural spread from infected Ailanthus.

w Status NH = susceptibility based on natural spread + artificial inoculation. $\mathrm{S}=$ susceptible based on inoculations with resiolation; PS = possibly susceptible, based solely on wilt and mortality following artificial inoculations without reisolation; $\mathrm{T}=$ tolerant, limited/no wilt, no mortality, but with fungal reisolation; $\mathrm{R}=$ resistant, outwardly asymtomatic despite vascular occlusion and discoloration.

x Values followed by no asterisk denotes mortality evaluations based on a late August 2013 evaluation, a single asterisk (*) denotes mortality evaluations based on 15-month postinoculation evaluations, a hashtag (\#) denotes mortality attributed to other abiotic/biotic agents.

y Bold values denote species from which $V$. nonalfalfae was reisolated following inoculation.

$\mathrm{z}$ sd denotes statistically significant difference based on Tukey's pairwise comparisons $(P=0.001)$. 
and circumferential extent. Unlike the yellow vascular discoloration within inoculated Ailanthus, in general, other inoculated species that were positive for vascular discoloration exhibited either a reddishbrown, brown, or black vascular discoloration characterized by either streaking or flecking (Figs. 4 and 5). V. nonalfalfae was reisolated from symptomatic wood tissues of one sugar maple and one red maple that exhibited no other symptoms of Verticillium wilt $>4$ years postinoculation.

In August 2013, the previously healthy nontarget species that had been inoculated in 2007 were evaluated one final time to assess tree status (living or dead) 6 years postinoculation. All inoculated species except white ash exhibited healthy crowns with no outward symptoms of disease or crown dieback. White ash dieback and mortality was attributed to infestations by the emerald ash borer (Agrilus planipennis Fairmaire) based on the presence of epicormic shoots, bark splitting, and serpentine galleries and D-shaped exit holes. In addition, one sugar maple and one red maple had succumbed from unknown causes between 2011 and 2013.

Field inoculations of nontarget species in 2009 to 2010. Inoculations of Ailanthus and 12 nontarget species in May 2009 confirmed susceptibility, as evidenced by foliar wilt and mortality, of Ailanthus and five additional nontarget species: black locust, eastern redbud, Japanese maple, northern catalpa, and sassafras (Table 3). Disease developed within 2 weeks of inoculation on all species except eastern redbud, which did not develop wilt symptoms until 14 weeks postinoculation (WPI) (September 2009), during the final disease rating of the 2009 growing season. All susceptible species exhibited wilt, vascular discoloration, and defoliation (Table 3, Fig. 5). Cessation of radial growth was detected in sassafras adjacent to the inoculation zones, whereas a localized ring of vessel occlusion was detected in black locust, after which normal growth resumed. In addition, epicormic sprouting along diseased stems and branches occurred on Ailanthus, sassafras, and northern catalpa. Mortality was observed in Ailanthus, Japanese maple, northern catalpa, and sassafras following wilt and defoliation of stems, although at a low incidence in the latter three species (Table 3).

Mean AUDPC values were significantly greater for inoculated Ailanthus (380.5), sassafras (221.0), and northern catalpa (215.8) than for all other species and controls 24 MPI (June 2011) $(P<0.001$, Table 3). The AUDPC value for Ailanthus was also significantly greater than for sassafras and northern catalpa $(P=0.0000$, Table 3$)$. AUDPC means for black locust (126.8) and eastern redbud (124.0) were not significantly different from the controls (119.0) or from each other $(P=1.0000)$, despite both species exhibiting some foliar wilt following inoculation.

AUDPC means for different susceptible species varied over time (Supplementary Table 3), emphasizing the importance of evaluating
AUDPC at various times during the growing season. For example, AUDPC values for sassafras and northern catalpa at 3 MPI (September 2009) were similar to that of Ailanthus. However, by 12 MPI (June 2010), AUDPC mean values were significantly greater for Ailanthus (172.5), since many trees died following initial wilt. In contrast, northern catalpa (127.4) and sassafras (127.4) recovered, resulting in lower AUDPC values and in rating divergence between the two groups $(P=0.0000$, Table 3$)$.

Evaluations of mean percentage crown dieback over a 24-month period supported AUDPC results and indicated that inoculated Ailanthus, northern catalpa, and sassafras had significantly greater mean crown dieback $(68.3 \%$ dieback) compared with the controls (27.5\% dieback) $(P=0.0088$, Fig. 6) at 3.5 MPI. By 24 MPI, only Ailanthus ratings were significantly different (100\% dieback) from the controls (25.0\% dieback) $(P=0.0000$, Fig. 6). Both northern catalpa and sassafras exhibited a $50 \%$ reduction in mean crown dieback between 12 MPI ratings and 24 MPI, indicating recovery (i.e., crown rebuilding) following inoculation (Fig. 6).

All Ailanthus, northern catalpa, and sassafras plants that had been inoculated in 2009 developed crown wilt, with an average wilt/ species of 100, 80, and 64\%, respectively (Table 3). Black locust and eastern redbud exhibited 35 and $20 \%$ crown wilt, respectively, on one symptomatic tree per species (Table 3 ). Mortality occurred on inoculated Ailanthus (100\% of inoculated trees), northern catalpa (20\%), and sassafras (20\%) following wilt, and on one Japanese maple tree, but the Japanese maple did not exhibit typical Verticillium wilt symptoms (Table 3). Instead, there was limited branch wilt and reddening of leaves as well as premature defoliation.

Eight of 13 inoculated species developed vascular discoloration, including all species that had previously exhibited wilt (Table 3). Species with vascular discoloration included Japanese barberry, American basswood, northern catalpa, American elm, Japanese maple, eastern redbud, sassafras, and staghorn sumac. Vascular discoloration was observed in all inoculated plants of all eight species and three of five Japanese barberry plants. American elm and basswood exhibited vascular discoloration only, with no other external wilt symptoms (Table 3, Fig. 5). Black tupelo and multiflora rose did not develop symptoms following inoculation. The color of vascular discoloration varied among species, but was usually reddishbrown, brown, or black streaking or flecking in the outer xylem (Fig. 5), although basswood developed a green discoloration. V. nonalfalfae was subsequently isolated from the vascular discoloration of symptomatic Ailanthus, northern catalpa, eastern redbud, and sassafras, but not other species (Table 3). Vascular staining was absent from all water-inoculated controls.

For the 2010 host range studies, artificial inoculations in the field confirmed that nine of 56 field-inoculated species were
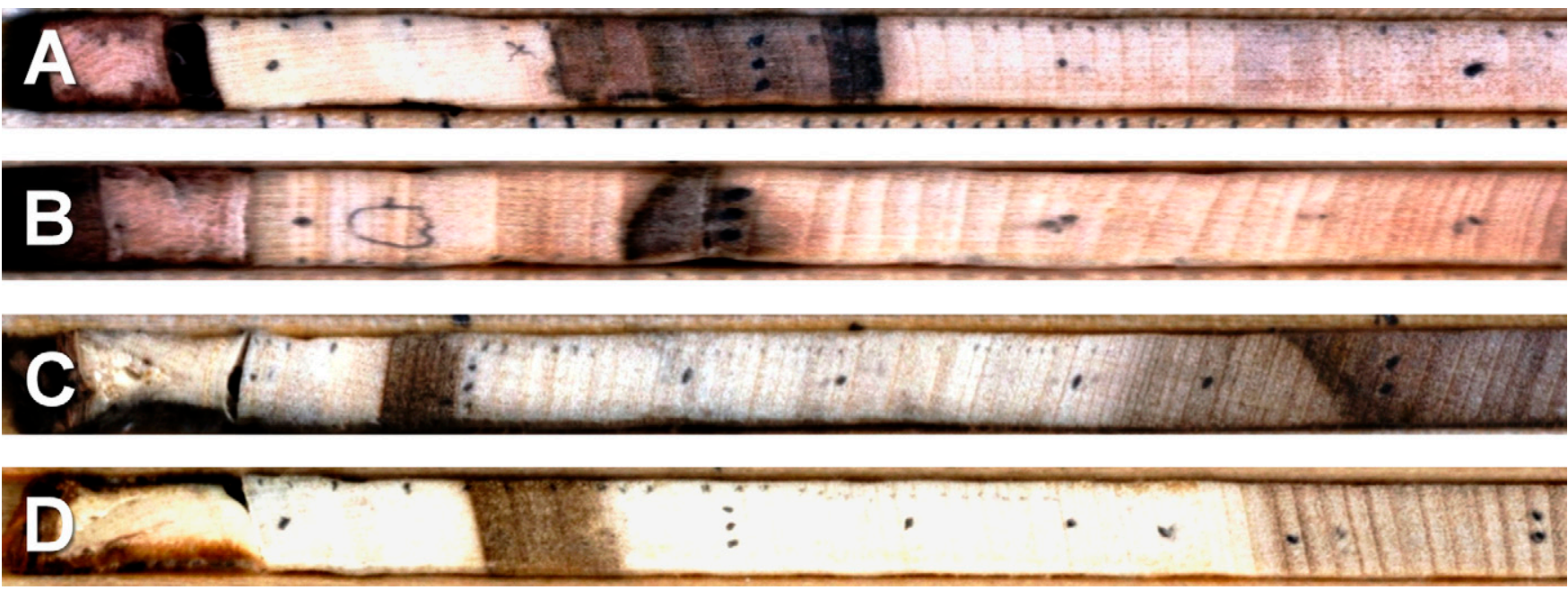

Fig. 4. Visualization of vascular discoloration in transverse increment cores from red maple (A and B) and tulip-poplar (C and D) following inoculation with Verticillium nonalfalfae isolate VnAa140 in 2007. Visualizations were conducted 5 years postinoculation (2012). Vertical triple pencil marks on cores denote the year 2000 . Inoculation in 2007 resulted in necrosis of sapwood in red maple (2 to 8 annual growth rings) and tulip-poplar (1 to 6 annual growth rings). Discoloration spanned the following years: A, 1997 to 2004 with enhanced discoloration from 1997 to 1999; B, 1999 to 2000; C, 2001 to 2006; and D, 2004 to 2006. 
susceptible (Table 3 ). Susceptible species included two positive control species (Ailanthus and striped maple); five nontarget species rated as susceptible based on 2009 artificial inoculations (black locust, northern catalpa, eastern redbud, Japanese maple, and sassafras); and two species not previously included in the 2009 studies, autumn olive and Norway maple (Table 3). Wilt developed on all but two of nine species within 4 WPI. Norway and striped maple developed symptoms within 1.5 to 2 MPI. Symptoms on all species included wilt, vascular discoloration, and defoliation. Stem sprouting along diseased stems and branches was common on Ailanthus, sassafras, and northern catalpa, and less frequent on black locust.

Mean AUDPC ratings at 15 MPI were significantly greater for inoculated Ailanthus (195.3), poison ivy (225.6), staghorn sumac (172.2), and striped maple (221.8) than for red elderberry (134.9) and all other species (58.8 to 105.9) $(P=0.000)$, which were not significantly different from noninoculated controls (61.5) (Table 3). Despite significantly higher mean AUDPC values for poison ivy, staghorn sumac, and red elderberry, $V$. nonalfalfae was never recovered from these three species. The mean AUPDC for red elderberry was significantly different from Ailanthus, poison ivy, staghorn sumac, and striped maple, but significantly greater than Amur corktree (76.3), black locust (58.8), northern catalpa (68.0), and sassafras (77.9), and the control $(P<0.05)$.

All Ailanthus, Amur corktree, northern catalpa, poison ivy, sassafras, staghorn sumac, and striped maple plants inoculated in 2010 wilted, exhibiting an average of 100, 63, 60, 100, 77, 100, and $100 \%$ crown wilt per tree for each species, respectively (Table 3 ).
Autumn olive, black locust, eastern redbud, Japanese maple, Norway maple, and red elderberry exhibited wilting on four to eight plants per species with $48,75,21,13,17$, and $78 \%$ average crown wilt per tree for each species, respectively (Table 3 ). Only one northern spicebush plant developed wilt following inoculation, but exhibited only $10 \%$ wilt.

Of the 16 species that exhibited wilt following inoculation, only three species (Ailanthus, poison ivy, and striped maple) exhibited $100 \%$ mortality (Table 3 ). The remaining species had mortality ranges from 10 to $90 \%$. Of these, three were invasive species (Amur corktree, autumn olive, Norway maple), one a nonnative ornamental (Japanese maple), and five were native plant species (black locust, eastern redbud, red elderberry, sassafras, and staghorn sumac). Two native species other than striped maple and poison ivy exhibited $>25 \%$ mortality (red elderberry $=80 \%$ and staghorn sumac $=90 \%$, Table 3). All northern catalpa and northern spicebush plants were still alive 39 MPI. Black birch exhibited $10 \%$ mortality (one tree) but the death appeared to be the result on a branch canker above the wilting branch (Table 3). Likewise, nine of 10 American chestnut trees wilted and died following inoculation, but were infected with the chestnut blight fungus, Cryphonectria parasitica (Murrill) Barr.

Vascular discoloration was evaluated $1 \mathrm{~m}$ above inoculation point on all inoculated species and controls. Thirty-two of 56 species exhibited vascular discoloration following artificial inoculation, including 14 species that had previously exhibited wilt (Table 3). Red elderberry, despite the high incidence of wilt and mortality following inoculation, did not exhibit vascular discoloration. Thirteen species,
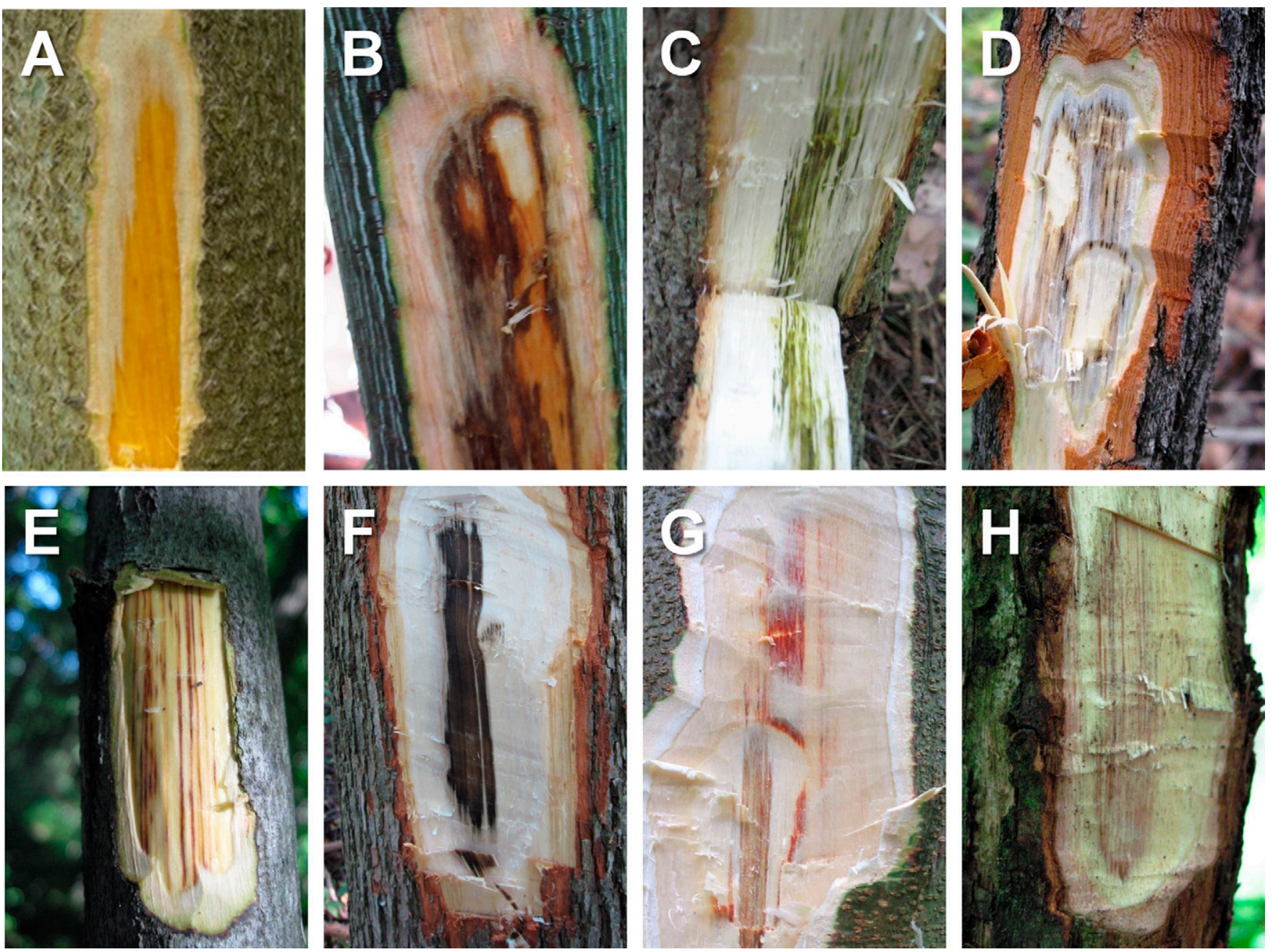

Fig. 5. Vascular discoloration associated with xylem vessel occlusion following inoculation of Verticillium nonalfalfae isolate VnAa140 in susceptible hosts A, Ailanthus; $\mathbf{B}$, striped maple; C, Norway maple; D, sassafras; and E, eastern redbud, as well as possibly tolerant/resistant tree species F, cucumber tree; G, honey locust; and $\mathbf{H}$, American elm. Reisolation of $V$. nonalfalfae confirmed in $A$ to $E$. 
including three exotic and nine native tree species, exhibited vascular discoloration, but no other symptoms (Table 3). Vascular discoloration was reddish-brown, brown, or black streaking or flecking in the vascular cambium, except in basswood, hackberry, and Norway maple where the discoloration was green (Fig. 5). V. nonalfalfae was subsequently isolated from the three species exhibiting only vascular discoloration: red maple, sugar maple, and Korean evodia (Table 3).

2010 greenhouse inoculations of potted nontarget species. Inoculations of potted greenhouse plants during July to September 2010 confirmed the susceptibility of two species (corkwood and tree-ofparadise) of the eight species evaluated (Table 3). Initial wilt symptoms developed first on crossvine (3 weeks), followed by corkwood (5 weeks), tree-of-paradise (6 weeks), and redbay ( 7 weeks). However, $V$. nonalfalfae was never recovered from crossvine or redbay. Symptoms included wilt, vascular discoloration, and defoliation. Stem and root sprouting also occurred on corkwood following defoliation.

Mean disease ratings (AUDPC) at 9 WPI were significantly greater for corkwood (17.3) and crossvine (11.3) than for Florida bitterbush (8.0) and controls (8.0) $(P=0.0000$ and 0.0380 , respectively, Table 3$)$. The mean AUDPC of corkwood was significantly greater than for crossvine $(P=0.0000)$.

All inoculated corkwood plants exhibited wilt, with an average of $54 \%$ per tree, and $30 \%$ of inoculated plants died (Table 3). Inoculated crossvine, redbay, and tree-of-paradise had two to eight symptomatic plants per species, which had 20,10 , and $16 \%$ average wilt/species, respectively (Table 3 ).

Corkwood, crossvine, Florida bitterbush, redbay, and tree-ofparadise exhibited vascular discoloration following inoculation (Table 3). Vascular discoloration occurred in all inoculated plants of corkwood, crossvine, and redbay whereas vascular discoloration occurred on 13 of 15 tree-of-paradise plants and five of 15 Florida bitterbush trees. Most symptomatic species exhibited either a reddishbrown, brown, or black streaking or flecking in the vascular cambium. $V$. nonalfalfae was subsequently isolated from symptomatic corkwood and tree-of-paradise, but not from other species.

\section{Discussion}

In this study we present extensive hazard and exposure risk assessments for $V$. nonalfalfae, the causal organism of lethal Verticillium wilt of the invasive A. altissima, on 71 nontarget tree and shrub species, as well as 78 Ailanthus seed sources spanning 26 states and one Canadian province. Overall, V. nonalfalfae exhibited a high degree of host specificity against the target host, Ailanthus, with limited impacts on nontarget plant species, most notably devil's walkingstick and striped maple. In addition, all A. altissima seed collections tested were susceptible.

Susceptibility of Ailanthus seedlings from various seed sources. Only Ailanthus seedlings from three seed sources (Indiana, Massachusetts, and Pennsylvania) showed significantly less disease incidence to $V$. nonalfalfae VnAa140 than seedlings from the 75 other seed sources. In these three seed sources, one or more inoculated seedlings exhibited vascular discoloration from which $V$. nonalfalfae was isolated, but did not exhibit wilt or mortality over the duration of the experiment (11 weeks). Although slower infection rates due to various factors could explain the lack of outward symptoms in these individuals at $11 \mathrm{WPI}$, it is important that these seed sources be retested in the future to see if Verticillium wilt can develop over longer time periods. Also, comparisons between root-dip inoculations and direct stem injections in these seed sources might prove informative.

Incidence of natural infections by $\boldsymbol{V}$. nonalfalfae on nontarget species within Ailanthus-inoculated forest stands. Artificial inoculations, especially when conducted in greenhouses and other controlled environment chambers, tend to overestimate the susceptible host range $(3,48)$. Artificial inoculations in controlled environments tend to be optimal for pathogen growth or insect development (in cases of classical biocontrol). Therefore, susceptibility doesn't necessarily indicate that symptomatic species would be "natural hosts" under suboptimal or optimal field conditions, or within a heterogeneous landscape (3). Although it is assumed that the accumulation of $V$. nonalfalfae in the rhizosphere and the larger environment in general by highly susceptible Ailanthus presumably creates a negative feedback for native plant species, as previously reported in other pathosystems (28), the high degree of specificity coupled with the low incidence of natural infections on nontarget "natural hosts" might suggest otherwise for the V. nonalfalfae-Ailanthus pathosystem.

Of the 10 nontarget species (including greenhouse plants) that showed susceptibility to artificial inoculations of VnAa140, only striped maple acquired the pathogen through natural spread within inoculated Ailanthus stands. One of the earlier reports of "V. albo-atrum" on a native forest species was also on striped maple in upstate NY in 1957 (18), supporting this species as a "natural host." V. nonalfalfae could not be isolated from wilting staghorn sumac in Ailanthus wilt epicenters, although wilt symptoms were observed in both artificial inoculations and, to a lesser extent, on co-occurring sumac in disease epicenters. Since $V$. nonalfalfae was not isolated, sumac cannot be considered a host until Koch's postulates are fulfilled. Devil's walkingstick, which was not included in the artificial inoculation studies due to its scarcity, exhibited wilt and mortality within inoculated Ailanthus stands and yielded $V$. nonalfalfae upon isolation. However, without formalized pathogenicity testing, it remains unclear if isolation of $V$. nonalfalfae from this host was coincidental. Interestingly, the exotic ambrosia beetle Euwallacea validus attacked all three nontarget species, as well as A. altissima $(24,25)$, suggesting a possible link between field susceptibility and beetle transmission of $V$. nonalfalfae. Followup

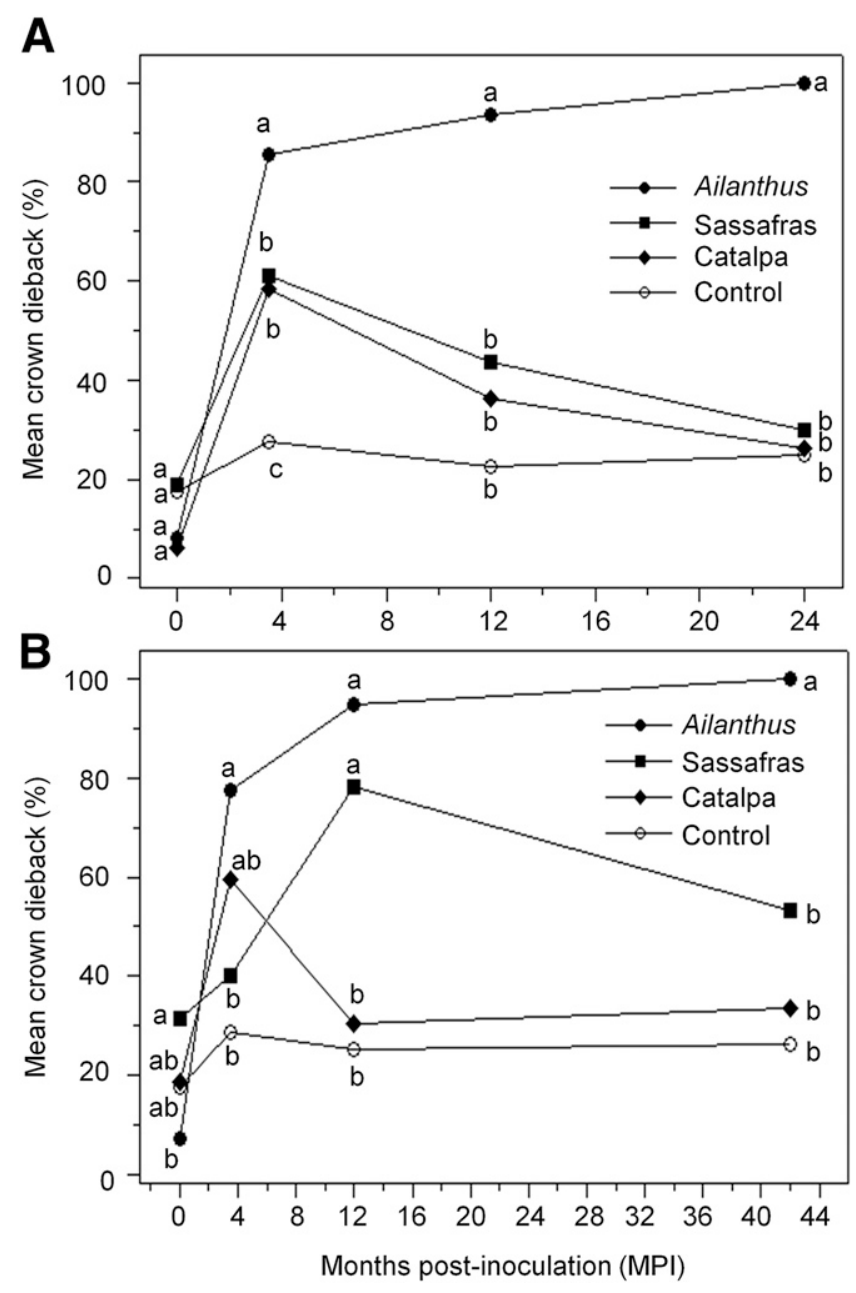

Fig. 6. Crown dieback progression following basal inoculation with Verticillium nonalfalfae isolate $\mathrm{VnAa} 140$ in A, 2009 and B, 2010. Controls consist of two waterinoculated stems per species for sassafras and northern catalpa for both years. 
studies should focus on these tripartite interactions, as well to determine if $V$. nonalfalfae is involved in sumac wilt and dieback within $A i$ lanthus wilt epicenters.

Three of the 10 nontarget species (Northern catalpa and Japanese and Norway maple) determined to be susceptible via stem inoculations either did not co-occur with Ailanthus or were present at low levels, and susceptibility could not be properly evaluated. The absence of these species from forested stands might be due to inhibition by Ailanthus allelopathic root exudates (29). If so, there is no practical way to evaluate such species in the field with regard to exposure risk. That is, $V$. nonalfalfae may never come in contact with these species in nature and therefore would not have the opportunity to infect them.

Table 2 shows incidence and density of several non-Ailanthus cohorts including black birch, black locust, red maple, striped maple, witch-hazel, and tulip-poplar, which are presumably little affected by Ailanthus's allelopathic compounds, since they grow intermingled with Ailanthus trees $(16,25)$. These species represent the most obvious choices for nontarget host range testing given their propensity to cohabitate sites regularly invaded by Ailanthus in Pennsylvania and possibly elsewhere in eastern United States.

This site-specific spread and delimitation of $V$. nonalfalfae is in sharp contrast to other fungi that have been adopted as classical biocontrol agents, which rapidly disseminate throughout a region to reach remote host populations located in areas otherwise inaccessible to conventional control interventions $(4,7,11)$. One potential limitation to rapid geographic spread of $V$. nonalfalfae is the density of $A i$ lanthus stems within a stand, which has been similarly hypothesized for spread of Uromycladium tepperianum in stands of invasive Acacia saligna in South Africa (49). Intraspecific root grafts among $A i$ lanthus stems may accelerate dissemination of the pathogen and disease progression, but grafts have not been well characterized and require future study.

Interspecific host range studies. Stem inoculations of 71 nonAilanthus species in the field (57 species), greenhouse (eight species), and follow-up studies on nontarget plants in 2007 (six species) demonstrated the susceptibility, evidenced by wilt, mortality, and fungal reisolation, of nine previously untested nontarget species (autumn olive, black locust, corkwood, eastern redbud, Japanese maple, northern catalpa, Norway maple, sassafras, and tree-of-paradise) and reconfirmed the susceptibility of one known nontarget host (striped maple). Of these susceptible species, only striped maple showed significant levels of mortality following inoculation, ranging from 70 to $100 \%$. Five additional inoculated susceptible nontarget native species (black locust, northern catalpa, redbud, and sassafras) exhibited wilt, but mortality was $<25 \%$ for any individual species, with sassafras showing the most significant mortality (21\%). Three exotic and/ or invasive tree and shrub species (autumn olive, Japanese maple, and Norway maple) showed moderate levels of wilt, yet mortality never exceeded $30 \%$ for any species, suggesting that this possible biocontrol agent should not be applied to other invasive woody hosts without further study.

Greenhouse studies revealed that one additional native tree species, corkwood, whose geographic range is limited to southeastern United States, also exhibited wilt and mortality following inoculation. Three additional inoculated species, crossvine, redbay, and tree-of-paradise, also native to southeastern United States, exhibited wilt but no mortality. Threatened in parts of its native range, corkwood tends to occupy habitats not favored by invaders such as Ailanthus that thrive in anthropogenically disturbed sites. Therefore, corkwood is not likely to be impacted by migration of $V$. nonalfalfae into its native range (17). Furthermore, relatively high temperatures (approximately $30^{\circ} \mathrm{C}$ ) have been reported to reduce "V. albo-atrum" growth to a yeast-like budding stage, whereas $V$. dahliae maintains moderate growth at relatively high temperatures (32). It is unknown if the yeast-like stage is pathogenic. These results suggest that $V$. nonalfalfae may be a more useful biocontrol agent of Ailanthus in more northern areas such as the Mid-Atlantic states where, coincidentally, Ailanthus densities are high and from which $V$. nonalfalfae has been isolated $(25,34,42,43)$.
The primary determinants for resistance to vascular wilt diseases including Verticillium wilt often occur within the root system, which may ultimately influence the frequency and intensity of initial vascular infections $(35,47)$. Stem inoculations bypass root defenses, in addition to flooding the vascular system with millions of spores. Therefore, positive inoculation results that suggest a susceptible host must be treated with caution. In contrast, lack of symptoms using these drastic inoculation techniques may reveal true tolerance or resistance. Caution must be exercised to ensure that a potential biocontrol agent is not prematurely rejected, or conversely accepted, based solely on such artificial studies (4).

Secondary determinants of host resistance to Verticillium $\mathrm{sp}$. include occlusion of vessels by tyloses, gums, or gels following initial establishment of the vascular wilt pathogen (5). Occlusions may either contribute to resistance by actively forming in advance of the pathogen to prevent and or limit vascular transport of propagules (47), or may contribute to pathogenesis by delaying formation of defensive host tyloses $(5,50)$. Indeed, our artificial inoculations revealed 21 species that showed only vascular discoloration following inoculation, with no wilt or mortality, and most exhibited vessel occlusions. Furthermore, the recovery rate of $V$. nonalfalfae from species exhibiting only vascular discoloration was approximately $15 \%$, whereas $V$. nonalfalfae was reisolated from $>50 \%$ of species that exhibited wilt. This finding supports the inference that occlusions were ineffective in preventing movement of propagules in vascular tissue of susceptible species exhibiting Verticillium wilt and mortality, but were effective for species that exhibited only vascular discoloration.

Recovery of $V$. nonalfalfae from three asymptomatic, inoculated trees may represent instances where a low level of systemic infection occurred, yet resulted in few if any symptoms. Alternatively, since distal streaking associated with Verticillium infection can exceed the extent of fungal colonization (41), it is possible that sampling $1 \mathrm{~m}$ above the inoculation point exceeded the area of fungal colonization. Recovery of $V$. nonalfalfae from asymptomatic red and sugar maple several years after inoculation both in this study and previous studies (40) offers support for this hypothesis. Whether or not such colonization will eventually cause significant Verticillium wilt remains unclear, but evaluation of radial growth response from these trees suggest long-term residency by Verticillium spp. has a negligible effect on tree health and growth (Kasson and Davis, unpublished data).

Vessel arrangement (ring porous versus diffuse porous) and number of tree rings present in the active sapwood also might play a role in susceptibility. For example, ring-porous northern catalpa has only one to two active sapwood rings, whereas diffuse porous maples have $>30$ sapwood rings that aid in water uptake (31). Such differences may explain how sugar and red maple often overcome vascular infections. In addition, young tulip-poplar seedlings have been reported to be susceptible to "V. albo-atrum," yet studies on large tulip-poplar trees contradicted these earlier findings. These reports with maples and tulip-poplar suggest that age (accumulation of additional conductive tissue) may have a protective or ameliorating effect against wilt development. Examination of asymptomatic tulip-poplar trees in our study area revealed 10 to 45 sapwood rings, supporting this hypothesis.

The study presented herein represents the most comprehensive host range study to date for $V$. nonalfalfae. Given the recent reclassification of this fungus, this study likely represents the only host range study conducted using confirmed isolates of $V$. nonalfalfae. Our results also suggest a narrower host range than previously reported for "V. albo-atrum" and may indicate a level of host adaption not previously reported for $V$. nonalfalfae. Of the 72 inoculated species, only three species (Ailanthus, devil's walkingstick, and striped maple) appear to be natural hosts that acquire the disease through nonanthropogenic dissemination. Staghorn sumac may also be another host, but followup studies are needed to validate earlier observations that were inconclusive. More importantly, the incidence of natural infections in the above species tended to be significantly lower than Ailanthus. These results presented in this paper offer support for the expanded adoption and dissemination of $V$. nonalfalfae VnAa140 to combat one of our forests' most notorious and entrenched invasive species, Ailanthus altissima. 


\section{Acknowledgments}

This research was supported by funding from the U.S. Department of Agriculture Forest Service, Forest Health Technology Enterprise Team, Morgantown, WV. We thank E. Rosko, J. Ross, and C. Yeckley for their assistance in the field. We thank the PA Department of Transportation, PA State Game Commission, PA Department of Conservation and Natural Resources, and U.S. Army Corps of Engineers for providing field study sites.

\section{Literature Cited}

1. Aldrich, P. R., Briguglio, J. S., Kapadia, S. N., Morker, M. U., Rawal, A., Kalra, P. Huebner, C. D., and Greer, G. K. 2010. Genetic structure of the invasive tree Ailanthus altissima in the Eastern United States cities. J. Bot. Article ID 795735. Online publication.

2. Auger, J., Perez, I., Fullerton, R. A., and Esterio, M. 2009. First report of Verticillium wilt of Gold Kiwifruit, Actinidia chinensis cv. Hort 16A, caused by Verticillium albo-atrum in Chile. Plant Dis. 93:553.

3. Barton (née Fröhlich), J. 2004. How good are we at predicting the field hostrange of fungal pathogens used for classical biological control of weeds? Biol. Control 31:99-122.

4. Barton, J. 2012. Predictability of pathogen host range in classical biological control of weeds: an update. BioControl 57:289-305.

5. Beckman, C. H. 1964. Host responses to vascular infection. Annu. Rev. Phytopathol. 2:231-252.

6. Bhat, R. G., and Subbarao, K. V. 1999. Host range specificity in Verticillium dahliae. Phytopathology 89:1218-1225.

7. Bruckart, W. L., Supkoff, D. M., and Yang, S. M. 1996. Indigenous plant pathogens in evaluations of foreign biological control candidates in the United States of America. Pages 71-77 in: Proceedings of the IX International Symposium on Biological Control of Weeds, 19-26 January 1996, Stellenbosch, South Africa. V. C. Moran and J. H. Hoffman, eds. University of Cape Town Press, Cape Town, South Africa.

8. Carter, J. C. 1938. Verticillium wilt of woody plants in Illinois. Plant Dis. Rep. 22:253-254.

9. Carter, J. C. 1940. Some isolations of Verticillium in Illinois during 1938 and 1939. Plant Dis. Rep. 24:133-134.

10. Correll, J. C., Gordon, T. R., and McCain, A. H. 1988. Vegetative compatibility and pathogenicity of Verticillium albo-atrum. Phytopathology 78:1017-1021.

11. Ding, J., Wu, Y., Zheng, H., Fu, W., Reardon, R., and Liu, M. 2006. Assessing potential biological control of the invasive plant, tree-of-heaven, Ailanthus altissima. Biocontrol Sci. Technol. 16:547-566.

12. Gilbert, G. S., and Webb, C. O. 2007. Phylogenetic signal in plant pathogen-host range. Proc. Natl. Acad. Sci. 104:4979-4983.

13. Goud, J. K. C., Termorshuizen, A. J., and van Bruggen, A. H. 2011. Verticillium wilt in nursery trees: damage thresholds, spatial and temporal aspects. Eur. J. Plant Pathol. 131:451-465.

14. Hansen, E. M., Parke, J. L., and Sutton, W. 2005. Susceptibility of Oregon forest trees and shrubs to Phytophthora ramorum: a comparison of artificial inoculation and natural infection. Plant Dis. 89:63-70.

15. Harrington, T. C., and Cobb, F. W. 1984. Verticillium albo-atrum on Ceanothus in a California forest. Plant Dis. 68:1012.

16. Harris, P. T., Cannon, G. H., Smith, N. E., and Muth, N. Z. 2013. Assessment of plant community restoration following Tree-of-Heaven (Ailanthus altissima) control by Verticillium albo-atrum. Biol. Invasions 15:1887-1893.

17. Herrick, N. J., Mcavoy, T. J., Snyder, A. L., Salom, S. M., and Kok, L. T. 2012. Host-range testing of Eucryptorrhynchus brandti (Coleoptera: Curculionidae), a candidate for biological control of tree-of-heaven, Ailanthus altissima. Environ. Entomol. 41:118-124.

18. Hibben, C. R. 1959. A new host for Verticillium albo-atrum Reinke \& Berth. Plant Dis. Rep. 43:1137.

19. Himelick, E. B. 1969. Tree and shrub hosts of Verticillium albo-atrum. Biol. Nat. Ill. Nat. Hist. Surv. 66:3-6.

20. Hubner, C. D., and Rebbeck, J. 2013. Ailanthus: A non-native urban weed is causing trouble in our forests. Research Review No. 22 (Spring 2014). USDA Forest Service Northern Research Station, Delaware, OH.

21. Inderbitzin, P., Bostock, R. M., Davis, R. M., Usami, T., Platt, H. W., and Subbarao, K. V. 2011. Phylogenetics and taxonomy of the fungal vascular wilt pathogen Verticillium, with the descriptions of five new species. PLoS ONE 6:e28341.

22. Inderbitzin, P., and Subbarao, K. V. 2014. Verticillium systematics and evolution: how confusion impedes Verticillium wilt management and how to resolve it. Phytopathology 104:564-574.

23. Kasson, M. T., Davis, M. D., and Davis, D. D. 2013. The invasive Ailanthus altissima in Pennsylvania: A case study elucidating species introduction, migration, invasion, and growth patterns in the Northeastern US. Northeast. Nat. 20 (Monogr. 10):1-60.
24. Kasson, M. T., O’Donnell, K., Rooney, A. P., Sink, S., Ploetz, R. C., Ploetz, J. N., Konkol, J. L., Carrillo, D., Freeman, S., Mendel, Z., Smith, J. A., Black, A. W., Hulcr, J., Bateman, C., Stefkova, K., Campbell, P. R., Geering, A. D. W., Dann, E. K., Eskalen, A., Mohotti, K., Short, D. P. G., Aoki, T. Fenstermacher, K. A., Davis, D. D., and Geiser, D. M. 2013. An inordinate fondness for Fusarium: Phylogenetic diversity of fusaria cultivated by ambrosia beetles in the genus Euwallacea on avocado and other plant hosts. Fungal Genet. Biol. 56:147-157.

25. Kasson, M. T., Short, D. P. G., O’Neal, E. S., Subbarao, K. V., and Davis, D. D. 2014. Comparative pathogenicity, biocontrol efficacy, and multilocus sequence typing of Verticillium nonalfalfae from the invasive Ailanthus altissima and other hosts. Phytopathology 104:282-292.

26. Lester, D. T. 1975. Variation in tolerance of American elm to the Verticillium wilt fungus. For. Sci. 21:227-231.

27. Malcolm, G. M., Kuldau, G. A., Gugino, B. K., and Jiménez-Gasco, M. D. M. 2013. Hidden host plant associations of soilborne fungal pathogens: an ecological perspective. Phytopathology 103:538-544.

28. Mangla, S., Inderjit, and Callaway, R. M. 2008. Exotic invasive plant accumulates native soil pathogens which inhibit native plants. J. Ecol. 96: 58-67.

29. Mergen, F. 1959. A toxic principle in the leaves of Ailanthus. Bot. Gaz. 121: 32-36.

30. Morehart, A. L., Donohue, F. M., III, and Melchior, G. L. 1980. Verticillium wilt of yellow poplar. Phytopathology 70:756-760.

31. Panshin, A. J., and Zeeuw, C. D. 1980. Textbook of Wood Technology. McGraw-Hill Book Co., New York.

32. Pegg, G. F., and Brady, B. L. 2002:Pages 293-340. in: Verticillium Wilts, Chapter 11. CAB International, Wallingford, U.K.

33. Rebbeck, J., Malone, M. A., Short, D. P. G., Kasson, M. T., O'Neal, E. S., and Davis, D. D. 2013. First report of Verticillium wilt caused by Verticillium nonalfalfae on tree-of-heaven (Ailanthus altissima) in Ohio. Plant Dis. 97: 999.

34. Robb, J. 2007. Verticillium tolerance: Resistance, susceptibility or mutualism? Can. J. Bot. 85:903-910.

35. Schall, M. J. 2008. Verticillium wilt of Ailanthus altissima. Ph.D. dissertation, The Pennsylvania State University, University Park, PA.

36. Schall, M. J., and Davis, D. D. 2009. Ailanthus altissima wilt and mortality: etiology. Plant Dis. 93:747-751.

37. Schall, M. J., and Davis, D. D. 2009. Verticillium wilt of Ailanthus altissima: susceptibility of associated tree species. Plant Dis. 93:1158-1162.

38. Schreiber, L. R., and Mayer, J. S. 1992. Seasonal variations in susceptibility and in internal inoculum densities in maple species inoculated with Verticillium dahliae. Plant Dis. 76:184-187.

39. Seiler, L. K. 2012. Effectiveness of Ailanthus altissima as a bioindicator of ozone pollution. Master's Thesis, The Pennsylvania State University, University Park, PA.

40. Sinclair, W. A., Smith, K. L., and Larsen, A. O. 1981. Verticillium wilt of maples: symptoms related to movement of the pathogen in stems. Phytopathology 71:340-345.

41. Smith, L. D., and Neely, D. 1979. Relative susceptibility of tree species to Verticillium dahliae. Plant Dis. Rep. 63:328-332.

42. Snyder, A. L., Kasson, M. T., Salom, S. M., Davis, D. D., Griffin, G. J., and Kok, L. T. 2013. First report of Verticillium wilt of Ailanthus altissima in Virginia caused by Verticillium nonalfalfae. Plant Dis. 97:837.

43. Snyder, A. L., Salom, S. M., and Kok, L. T. 2014. Survey of Verticillium nonalfalfae (Phyllachorales) on tree-of-heaven in the southeastern USA. Biocontrol Sci. Technol. 24:303-314.

44. Talboys, P. W. 1960. A culture-medium aiding the identification of Verticillium albo-atrum and V. dahliae. Plant Pathol. 9:57-58.

45. Townsend, A. M., and Hock, W. K. 1973. Tolerance of half-sib families of red maple to Verticillium wilt. Phytopathology 63:673-676.

46. Townsend, A. M., Schreiber, L. R., Hall, T. J., and Bentz, S. E. 1990. Variation in response of Norway maple cultivars to Verticillium dahliae. Plant Dis. 74: 44-46.

47. Vallad, G. E., and Subbarao, K. V. 2008. Colonization of resistant and susceptible lettuce cultivars by a green fluorescent protein-tagged isolate of Verticillium dahliae. Phytopathology 98:871-885.

48. Watson, A. K. 1985. Host specificity of plant pathogens in biological weed control. Pages 577-586 in: Proc. VI Int. Symp. Biol. Control Weeds, Vancouver, BC, Canada.

49. Wood, A. R. 2012. Uromycladium tepperianum (a gall-forming rust fungus) causes a sustained epidemic on the weed Acacia saligna in South Africa. Australas. Plant Pathol. 41:255-261.

50. Yadeta, K. A., and Thomma, B. P. 2013. The xylem as battleground for plant hosts and vascular wilt pathogens. Front. Plant Sci. 4:97. 